\title{
Pseudomonas Species as Producers of Eco-friendly Polyhydroxyalkanoates
}

\author{
Justyna Mozejko-Ciesielska' ${ }^{1} \cdot$ Karolina Szacherska $^{1} \cdot$ Paulina Marciniak $^{1}$
}

Published online: 18 March 2019

(c) The Author(s) 2019

\begin{abstract}
Polyhydroxyalkanoates (PHAs) have been produced by various bacteria as natural polymers stored in bacterial cells as a source of carbon and energy. They are currently preferred biomaterials for use in many industrial fields instead of conventional non-degradable plastics. Due to their unique properties they can reduce pollution caused by the increasing global polymer demand. Pseudomonas species have been chosen as PHAs producers in many recent studies. Being metabolically versatile and possessing a remarkable tolerance to a wide range of carbon sources, these bacteria have become an efficient cell factory for PHAs production. Currently, attention is focused on the design of Pseudomonas strains to increase their ability to accumulate PHAs in the cell and modifying their biosynthetic pathways to obtain strains with modified compositions and improved properties. This article discusses the current state of knowledge of polyhydroxyalkanoates synthesized by Pseudomonas species which are industrially important microorganisms. This review provides an overview of recent trends towards PHA production, focusing on the utilization of low-cost carbon sources, fermentation strategies, PHAs properties and their uses as valuable bioproducts.
\end{abstract}

Keywords Biodegradable polymers $\cdot$ Bioproducts $\cdot$ Polyhydroxyalkanoates $\cdot$ Pseudomonas sp.

\section{Introduction}

Due to their excellent properties, petroleum-based plastics are intensively used in everyday life and are an essential part of modern society. Because of their stability and durability they are replacing glass, wood, metal in many industrial and medical applications. It is estimated that over 300 million tons of plastics are produced in the world annually and about $50 \%$ of this volume is for disposal applications - products that are discarded within a year of their purchase [1]. Plastic waste management has become a global issue. However, being non-biodegradable, synthetic plastics are persistent and accumulate in the natural environment resulting in a significant burden on waste management. Furthermore, it has become evident that fossil fuel reserves are finite and will be depleted soon. Therefore, there is a need to develop

Justyna Mozejko-Ciesielska justyna.mozejko@uwm.edu.pl

1 Department of Microbiology and Mycology, Faculty of Biology and Biotechnology, University of Warmia and Mazury in Olsztyn, Oczapowskiego 1A, 10-719 Olsztyn, Poland new technologies for producing materials that have polymer-like properties and degrade after being discarded [2]. Among the various types of biodegradable polymers polyhydroxyalkanoates (PHAs) are especially attractive because they have useful properties due to the fact that they are biodegradable, non-toxic and biocompatible. PHAs are stored intracellularly by many microorganisms (gram-positive and gram-negative bacteria) as carbon and energy reserves [3]. For the first time, they were obtained from Bacillus megaterium in 1926 by French researcher Lemoigne [4]. Later, it was found that PHAs are accumulated by microorganisms as the reserve materials of carbon and energy. Since then, many companies have been set up to commercialize polyhydroxyalkanoates. Large scale PHA producers sell them as raw materials in the form of pellets or powder. PHAs are also marketed as the end-product with a defined applications. They are developed as additives for PVC and PLA, micropowder for cosmetics, sutures or films for medical applications [5]. However, the global PHAs market is still small compared to petroleum-based polymer production. According to the latest market data published by European Bioplastics [6], global biopolymers production reached 2.11 millions tonnes in 2018, including $1.4 \%$ of PHAs. Therefore, both 
industry and research put great effort into the screening of host producers used for fermentative PHAs production and to optimize the bioprocess towards the ultrahigh productivity of these biopolymers.

Many studies provide data on several PHA producers. It is well known that microorganisms capable of synthesizing PHAs can be divided into two groups. Bacteria belong to the first group are able to synthesize polyhydroxyalkanoates under nutrient limitation such as oxygen, nitrogen or phosphorus and they do not accumulate PHAs in their growth phase. The second group is presented by microorganisms that accumulate biopolymers during the growth phase and do not need to limit the nutrients [7].

Pseudomonas strains are especially extensively studied as metabolically versatile bacteria which have become efficient cell factories for the production of value-added compounds [8]. Due to their versatility, degradative potential and capacity to use a wide range of carbon sources, they are considered to be attractive candidates in a number of biotechnological applications. Biopolymers extracted from these bacteria can be used in various sectors from consumable goods to medicine $[9,10]$.

This review gives insights into recent challenges and progress in PHAs synthesis by Pseudomonas species. It provides an overview of recent trends towards PHAs production focusing on the development of fermentation strategies, utilization of different carbon sources, properties of PHAs and their use as valuable environmentally-friendly bioproducts.

\section{Structure, Classification and Biochemical Pathways}

Polyhydroxyalkanoates are synthesized in the bacterial cells as insoluble granules that form primarily a reservoir of carbon and energy. It has been proven that the biological function of PHAs is far more comprehensive. The involvement of PHA in stress resistance of microbial cells has been recently discussed and summarized by Obruca et al. [11]. Recent studies revealed that the presence of PHA in bacterial cells can help bacteria to preserve cell integrity when exposed to sudden osmotic imbalances [12]. In addition, PHA granules can serve as a potent cryoprotectant against the adverse effects of freezing-thawing cycles [13]. Moreover, 3-hydroxybutyrate was evaluated to be an enzyme-protective agent against heating and oxidative damage [14]. Intracellular PHA granules measure a diameter of 0.2 to $0.5 \mathrm{~mm}$. Cytoplasmic PHA granules consist of an amorphous PHAs fraction that forms a hydrophobic core surrounded by proteins bound to the PHA granule. The formation process of the polyhydroxyalkanoate granules is shown in Fig. 1. These biopolyester surfaces are covered by numerous phospholipids and proteins that play an important role in the synthesis, degradation and regulation of their synthesis process [15]. One of the most numerous proteins that coat the surface of the granules are phasins, and it has been shown that the levels of coverage range from 27 to 54\% [16]. Cytoplasmic granules can be visualized by phase contrast microscopy due to their high refractivity or by means of dyes such as Nile red and Sudan Black B [17]. It has been reported that under conditions corresponding to the biopolymer biosynthesis, some bacteria are able to produce as much as $90 \%(\mathrm{w} / \mathrm{w})$ PHAs of cell dry weight [18]. Recently, it has been shown that bacterial cultures lengthen the cells in order to control the PHA volume portion so that it does not exceed about $40 \%$ of the cell volume [19].

PHAs are polyesters that consist of hydroxylic acid (HA) monomers linked by an ester bond. The formation of the bond occurs by combining the carboxyl group of the monomer with the hydroxyl group of the adjacent group [21]. The polyhydroxyalkanoates may have a diversified structural composition depending on the bacterial strain used and the carbon source provided during cultivation. Biopolymers can be divided into two groups due to the number of carbon atoms in the monomer units: short-chain-length polyhydroxyalkanoates (scl-PHAs) and medium-chain-length polyhydroxyalkanoates (mcl-PHAs) [22]. Scl-PHAs contain from 3 to 5 carbon atoms in each monomer units and

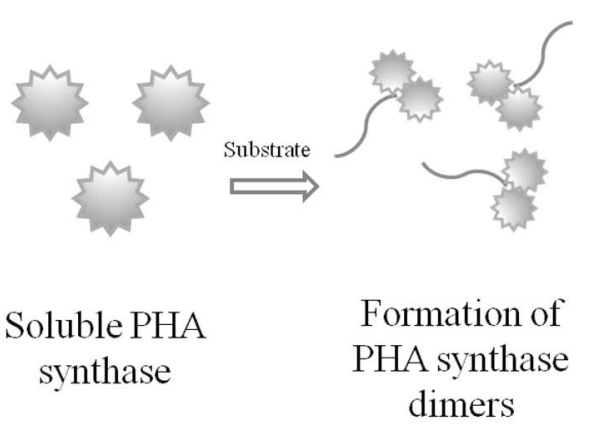

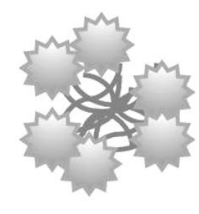

The process of creating micelles

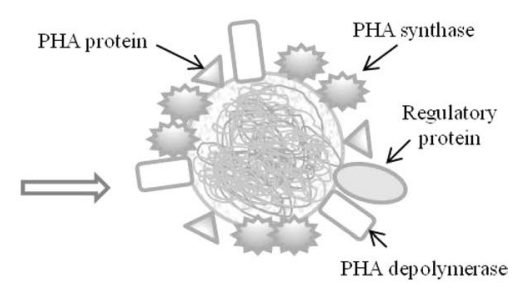

Mature PHA

granule with

attached proteins

Fig. 1 PHAs granule formation process. Modified according to Rehm [20] 
mcl-PHAs consist of 6-14 carbon atoms in each unit. The most commonly synthesized scl-PHAs are poly-3-hydroxybutyrate $[\mathrm{P}(3 \mathrm{HB})]$. It is a crystalline polymer with a fragile, rigid structure that has a high melting point and a low glass transition temperature. $\mathrm{P}(3 \mathrm{HB})$ is produced by numerous microorganisms, including Cupriavidus necator and Alcaligenes latus. Mcl-PHAs like poly-3-hydroxyoctanoate $[\mathrm{P}(3 \mathrm{HO})]$ or poly-3-hydroxyhexanoate $[\mathrm{P}(3 \mathrm{HHx})]$ are more desirable than scl-PHAs because of high elasticity with low crystallinity and tensile strength as well as a high melting point, as shown in Table 1 [21]. They are synthesized mainly by Pseudomonas species. In addition, some bacterial strains are able to scl-, mcl- and scl-mcl-copolymers. To date, at least 150 different monomer possessing various structures have been found. Different functional groups on

Table 1 Comparison of properties of scl-PHAs with mcl-PHAs

\begin{tabular}{lll}
\hline Properties & $\begin{array}{l}\text { Homopolymer } \\
\text { scl-PHAs }\end{array}$ & $\begin{array}{l}\text { Homopoly- } \\
\text { mer mcl- } \\
\text { PHAs }\end{array}$ \\
\hline Crystallinity $(\%)$ & 80 & 40 \\
Melting temperature $\left({ }^{\circ} \mathrm{C}\right)$ & 179 & 86 \\
Glass transition temperature $\left({ }^{\circ} \mathrm{C}\right)$ & 4 & -40 \\
Tensile strength $(\mathrm{Mpa})$ & 5 & 20 \\
Young's modulus $(\mathrm{Gpa})$ & 3.5 & $1-2$ \\
Elongation to break $(\%)$ & 40 & 300 \\
Resistance to UV light & Good & Good \\
Resistance to solvents & Weak & Weak \\
Biodegradability & Good & Good \\
\hline
\end{tabular}

scl-PHAs short-chain-length polyhydroxyalkanoates, mcl-PHAs medium-chain-length polyhydroxyalkanoates the monomer chain (such as halogen, epoxy-, hydroxy-, carboxyl- and esterified carboxyl) have also been discovered [23].

The type of polyhydroxyalkanoates produced depends on the metabolic pathway of the bacterium being used. Carbon sources are metabolized differently in bacteria. Bacteria belonging to Pseudomonas species involve two metabolic pathways to generate precursors for mcl-PHAs synthesis (Fig. 2). Each pathway uses a different substrate to provide 3-hydroxyacyl (3HA) precursors, which are then used to synthesize mcl-PHAs. Aliphatic carbon sources, such as fatty acids, are degraded by pseudomonads via the $\beta$-oxidation process. This pathway is involved in the oxidation of fatty acids into enoyl-CoA, (S)-3-hydroxyacyl-CoA and (R)-3-ketoacyl-CoA. They are then converted into (R)3-hydroxyacyl-CoA. Pseudomonas species are also able to use the de novo synthesis fatty acid pathway to synthesize mcl-PHA monomers from unrelated carbon sources, such as glucose, gluconate or ethanol [24]. In this process, these substrates are oxidized into acetyl-CoA and then converted by a series of reactions into malonyl-CoA and activating by transacylation to (R)-3HA-acyl carrier protein (ACP). The resulting acyl-ACP and malonyl-ACP intermediates are transformed into (R)-3-hydroxyacyl-ACP being further elongated by successive two-carbon units. In most pseudomonads, the specific transacylase PhaG transforms acyl-ACP intermediates into (R)-3-hydroxyacyl-CoA [25].

The synthesis of polyhydroxyalkanoates by microorganisms is possible due to the substrate specificity of the PHA polymerase, i.e. $\alpha-/ \beta$-hydrolase family enzymes catalysing the polymerization of (R)-3-hydroxyacyl-CoA thioester monomers. PHA synthases are divided into four groups

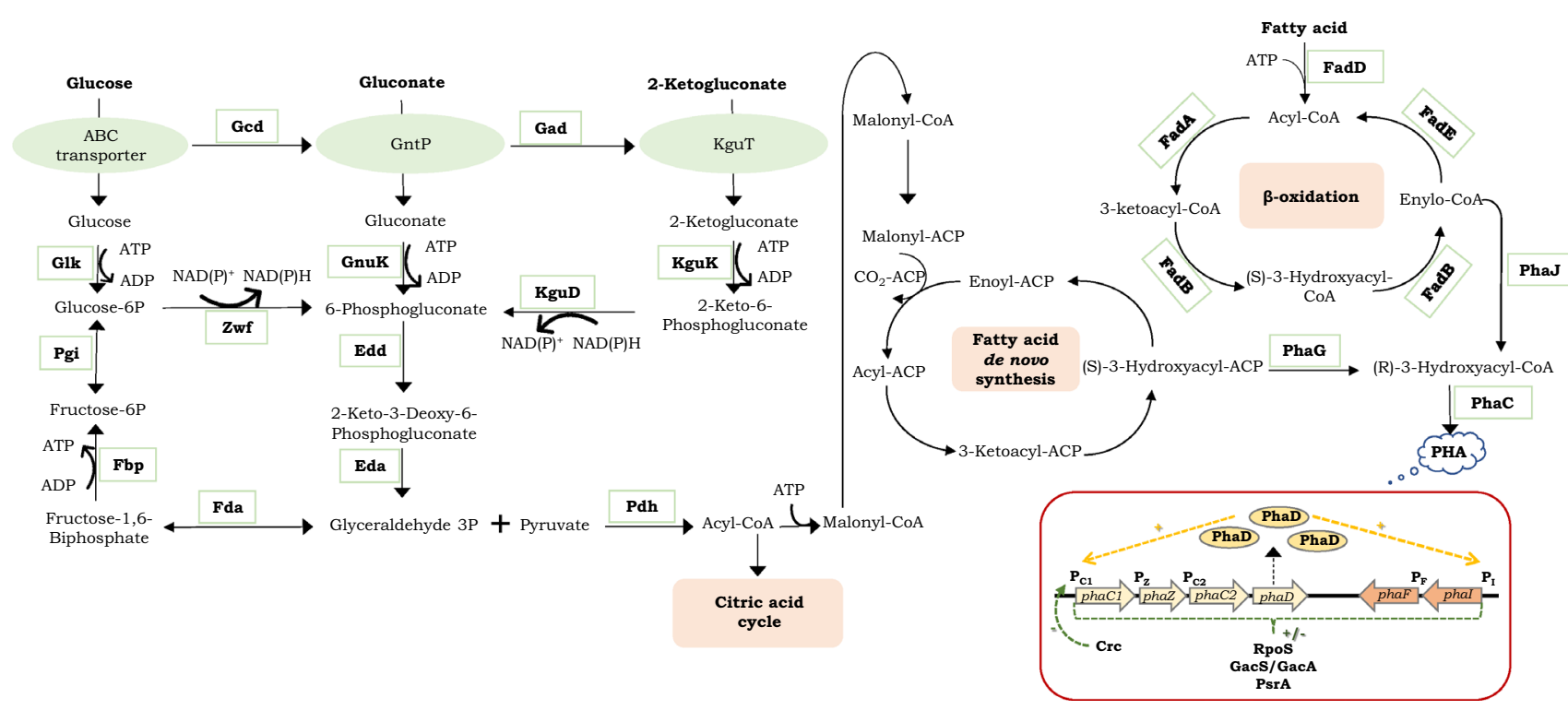

Fig. 2 Metabolic pathways and regulatory network of PHAs metabolism in Pseudomonas species 
based on their substrate specificity and subunit composition [26]. Class I and II synthases consist of one PhaC subunit, whose molecular mass is in the range of $61-73 \mathrm{kDa}$ [27]. Class III and IV synthases contain two different subunits. Class III synthase has PhaC and PhaE subunits with a similar molecular mass $-40 \mathrm{kDa}$. Class IV synthases consists of two subunits: PhaC and PhaR. Classes I, III, and IV use short-chain-length monomers, while class II uses mediumchain-length monomers being clearly different than other classes [28]. The class II of PHA synthase was found in Pseudomonas species.

In pseudomonads six proteins have been characterized as being essential for the accumulation and synthesis of polyhydroxyalkanotes: two polymerases (PhaC1, PhaC2) depolymerase (PhaZ), two phasins (PhaI, PhaF) and two regulatory proteins (PhaD, PhaG). In Pseudomonas species the pha cluster is very well-conserved and is organized into two operons phaC1ZC2D and phaFI. The PhaC1, PhaC2, $\mathrm{PhaZ}$ and $\mathrm{PhaD}$ proteins are encoded by genes transcribed in the same direction, whereas the $\mathrm{PhaF}$ and $\mathrm{PhaI}$ proteins are transcribed in the opposite direction [29]. It is well-known that $p h a C l$ and $p h a C 2$ genes are responsible for mcl-PHAs synthesis, while the phaZ gene allows the hydrolysis of accumulated biopolymers. PhaD is the only known protein that is not bound to PHA granule surface. It encodes the putative transcription regulator from the TetR family, which plays an essential role in the PHA biosynthesis. The mechanisms of action of $p h a D$ gene are still unknown, however it was postulated that it prevents expression or binding to major granule proteins leading to mcl-PHA accumulation [30]. PhaF and PhaI are associated with granule formation. They are believed to facilitate a segregation of the granules during cell division serving as an interface between the granule and the cytoplasm [31]. It was recently reported that the PhaF phasin plays a role in the control of Pseudomonas putida shape and length [32]. Sierro [33] revealed that the activity of the phaF gene is reinforced by the presence of $\mathrm{PhaD}$, resulting in the production of higher amounts of PhaF and PhaI phasins. That author also showed that PhaI appears to block the Pc1, $\mathrm{Pc} 2$ and Pi promoter-driven expression, while $\mathrm{PhaD}$ is able to induce both phasins (PhaF and PhaI). The expression of the $p h a$ genes is under the control of global transcriptional regulators such as the Crc, RpoS, PsrA and GacS/GacA systems (Fig. 2). The regulatory network that could drive the PHA cycle in pseudomonads has been reviewed in detail by Prieto et al. [34].

It has been suggested that PhaG encoded transacylase, which is not co-localised with the PHA biosynthesis gene cluster, could also be involved in PHA biosynthesis from non-related carbon sources, such as gluconate and glucose, linking fatty acid de novo biosynthesis with PHA biosynthesis. It is known that Pseudomonas putida GPo1 is incapable of synthesizing mcl-PHAs out of a structurally-unrelated carbon source, because of the lack of PhaG transcription [35]. However, Możejko-Ciesielska et al. [36] recently added to these findings by showing that $p h a G$ expression is associated with mcl-PHA synthesis on oleic acid (a structurallyrelated carbon source), suggesting that PhaG may play a role in this process as well. An association between increased phaG expression and mcl-PHAs synthesis on oleic acid was also found using the $P$. putida KT2440 relA/spoT mutant [37]. All the above-mentioned interactions show that the regulation of the PHA accumulation process seems to be complex. It is likely that this complexity does not only result from the effects of PhaD, PhaF or PhaI but also from other, yet-undiscovered proteins which affect the activity of promoters of the whole pha gene cluster.

\section{Fermentation Strategies}

The productivity of polyhydroxyalkanoates by bacteria is dependent on many factors, including the carbon sourceto-nitrogen source ratio, cultivation period, temperature, $\mathrm{pH}$ and the presence of macro and microelements [38]. However, the most important factor is a species of bacteria that has the ability to accumulate biopolymers. Many microorganisms have been studied for PHA synthesis but most of them do not have a promising capacity to synthesize and accumulate these biopolyesters. The PHA industrial producer should meet several criteria, such as the ability to metabolize raw carbon sources, to achieve a good growth rate and a high biopolymer content in bacterial cells. A number of Pseudomonas species have been reported to synthesize polyhydroxyalkanoates in satisfactory amounts and at a low cost [39]. The PHA productivity in bacteria belonging to Pseudomonas genus could be so high as during bioprocesses using other bacterial genera such as Cupriavidus, Burkholderia, Haloferax. The fermentations processes conducted with the above-mentioned prokaryotes were comprehensively reviewed by Możejko-Ciesielska and Kiewisz [40].

To optimize PHA yield, various types of fermentation strategies have been used, including batch, fed-batch and continuous processes. To enhance polymer productivity by the bacteria within a short time, cultivations can be carried out under varied conditions. Table 2 gives an overview of the results obtained using various cultivation strategies and employing different Pseudomnas species as PHA producers.

\section{Batch Cultivations}

Due to the reasonable overall production costs, batch fermentation is widely used in industrial fermentation processes. It is a closed cultivation strategy based on the supplementation of the culture medium with a carbon source at the beginning of the process and the removal of the 
Table 2 Summary of results of different strategies fermentation for PHAs production by Pseudomonas sp.

\begin{tabular}{|c|c|c|c|c|c|c|c|c|}
\hline Microbial strain & Carbon sources & Biomass $\left(\mathrm{g}^{-1}\right)$ & PHA content $(\%)$ & $\begin{array}{l}\mathrm{M}_{\mathrm{w}} \\
(\mathrm{kDa})\end{array}$ & $\begin{array}{l}\mathrm{M}_{\mathrm{n}} \\
(\mathrm{kDa})\end{array}$ & $\mathrm{T}_{\mathrm{m}}\left({ }^{\circ} \mathrm{C}\right)$ & $\mathrm{T}_{\mathrm{g}}\left({ }^{\circ} \mathrm{C}\right)$ & References \\
\hline \multicolumn{9}{|l|}{ Batch fermentation } \\
\hline Ps. putida GO16 & Terephthalic acid & 1.0 & 27.0 & 7.4 & 3.7 & 35 & -53 & {$[41]$} \\
\hline Ps. putida $\mathrm{GO} 19$ & & & 23.0 & 12.3 & 5.2 & 34 & -53 & \\
\hline $\begin{array}{l}\text { Ps. frederiksbergen- } \\
\text { sis GO23 }\end{array}$ & & & 24.0 & 9.3 & 4.4 & 35 & -53 & \\
\hline $\begin{array}{l}\text { Ps. oleovorans } \\
\text { ATCC } 29347\end{array}$ & Jatropha curcas oil & - & 26.06 & 166.8 & 131.8 & $150-160$ & NO & {$[42]$} \\
\hline \multirow{3}{*}{$\begin{array}{r}\text { Ps. aeruginosa } \\
\text { ATCC } 27853\end{array}$} & Oleic acid & 0.38 & 15 & 57 & 26 & 50 & -52 & [43] \\
\hline & Erucic acid & 0.866 & 9.3 & 122 & 63 & 50 & -46 & \\
\hline & Nervonic acid & 0.416 & 10 & 114 & 56 & 50 & -43 & \\
\hline \multirow[t]{3}{*}{ Ps. putida $\mathrm{KT} 2442$} & Decanoic acid & 5.78 & 15.2 & ND & ND & ND & ND & {$[44]$} \\
\hline & Dodecanoic acid & 6.96 & 14.9 & 100.0 & 80.0 & 53 & -44 & \\
\hline & Tetradecanoic acid & 2.74 & 21.82 & ND & ND & $\mathrm{ND}$ & ND & \\
\hline \multirow[t]{4}{*}{ Ps. putida KT2442 } & Hexanoate & 3.01 & 13.5 & 272.0 & 206.0 & ND & -28.19 & {$[45]$} \\
\hline & Heptanoate & 4.11 & 28.2 & 455.0 & 252.0 & no & -32.13 & \\
\hline & Octanoate & 4.64 & 28.9 & 180.0 & 148.0 & 66.06 & -38.38 & \\
\hline & Nonanoate & 3.90 & 57.4 & ND & ND & ND & ND & \\
\hline Pseudomonas sp. & Corn oil & 12.53 & 35.63 & ND & ND & $\mathrm{ND}$ & ND & [46] \\
\hline $\begin{array}{l}\text { Pseudomonas sp. } \\
\text { TN301 }\end{array}$ & Naphthalene & 0.48 & 23.0 & ND & ND & ND & ND & [47] \\
\hline Ps. putida CA-3 & Volatile fatty acids & 1.56 & 39 & ND & ND & ND & ND & [48] \\
\hline Ps. putida Bet001 & $\begin{array}{l}\text { Fatty acids } \\
\left(\mathrm{C}_{8: 0} \text { to } \mathrm{C}_{18: 1}\right)\end{array}$ & $9.8-15.5$ & $49.7-68.9$ & $60.06-77.66$ & $13.61-38.69$ & $43.3-66.5$ & $-1.0-1.0$ & [49] \\
\hline \multicolumn{9}{|c|}{ Fed-batch fermentation } \\
\hline \multirow[t]{3}{*}{ Ps. putida $\mathrm{KT} 2440$} & Glucose & 2.0 & 1.7 & ND & ND & ND & ND & {$[50]$} \\
\hline & Glycerol & 1.4 & 1.6 & ND & ND & ND & ND & \\
\hline & Citrate & 1.8 & 0.4 & ND & ND & ND & ND & \\
\hline \multirow[t]{2}{*}{ Ps. puitda KTQQ20 } & Decanoic acid & 0.94 & 4.61 & 361.4 & 248.6 & 72.2 & -37.21 & {$[44]$} \\
\hline & Dodecanoic acid & 1.03 & 9.19 & 155.5 & 119.4 & 77.62 & -32.49 & \\
\hline \multirow{3}{*}{$\begin{array}{l}\text { Pseudomonas sp. } \\
\text { SGP4502 }\end{array}$} & Acetate & 0.57 & 10.1 & 158.5 & 73.4 & ND & ND & {$[51]$} \\
\hline & Octanoate & 1.80 & 28.0 & 260.01 & 107.0 & ND & ND & \\
\hline & Dodecanoate & 0.30 & 36.1 & 169.5 & 76.7 & ND & ND & \\
\hline $\begin{array}{l}\text { Ps. aeruginosa BP } \\
\quad \mathrm{C} 1\end{array}$ & glucose & 7 & 14.7 & 5.9 & 5.6 & $139 / 227$ & 34.3 & {$[52]$} \\
\hline \multirow[t]{3}{*}{ Ps. mosselii $\mathrm{TO} 7$} & Octanoic acid & 1.70 & 45.20 & 218.3 & 98.7 & ND & $\mathrm{ND}$ & {$[53]$} \\
\hline & Palm kernel oil & 4.31 & 47.10 & $\mathrm{ND}$ & ND & $37.2 / 55.7$ & -42.8 & \\
\hline & Soybean oil & 3.76 & 49.82 & ND & ND & 46 & no & \\
\hline Ps.putida & Glucose & 61.8 & 67.1 & ND & ND & ND & ND & [8] \\
\hline Ps. putida $\mathrm{KT} 2440$ & $\begin{array}{l}\text { Glucose, Nonanoic } \\
\text { acid }\end{array}$ & 2.85 & 32.0 & ND & ND & ND & ND & {$[54]$} \\
\hline \multirow{3}{*}{$\begin{array}{r}\text { Ps. aeruginosa } \\
\text { ATCC } 27853\end{array}$} & Heptadecanoic & 1.6 & 9.81 & 77 & 48.1 & 52 & -45 & {$[55]$} \\
\hline & Nonadecanoic & 2.37 & 5.36 & 97 & 48.5 & 48 & -43 & \\
\hline & Heneicosanoic & 2.74 & 0.255 & 188 & 110.6 & 49 & -39 & \\
\hline \multicolumn{9}{|c|}{ Continuous fermentation } \\
\hline \multirow{2}{*}{$\begin{array}{l}\text { Ps. oleovorans } \\
\text { ATCC } 29347\end{array}$} & Citrate & 1.68 & 6 & ND & ND & $\mathrm{ND}$ & ND & {$[56]$} \\
\hline & $n$-Octane & 1.75 & 37 & ND & ND & ND & ND & \\
\hline Ps. putida GPol & $\begin{array}{l}\text { 5-phenylvalerate, } \\
\text { octanoate, and } \\
\text { 10-undecenoate }\end{array}$ & $0.98-1.06$ & $16-29$ & ND & ND & ND & ND & {$[57]$} \\
\hline Ps. putida KT2440 & $\begin{array}{l}\text { Potassium octanoate, } \\
\text { Potassium } \\
\text { 10-undecenoate }\end{array}$ & ND & 42 & ND & ND & ND & ND & {$[58]$} \\
\hline
\end{tabular}

$M_{\mathrm{w}}$ weight avaerage molecular weight, $M_{n}$ number avaerage molecular weight, $T_{g}$ glass transition temperature, $T_{m}$ melting temperature, $N D$ not determined 
biopolymer at its end. The entire process is maintained in a constant and undisturbed condition [59]. In batch fermentation, two approaches can be conducted: one-stage and two-stage cultivation [60]. In the one-stage process, the cell growth, synthesis and accumulation of the biopolymer take place simultaneously. The two-stage process involves two phases: microbial growth and biopolymer accumulation [61]. In the first stage the cultivation is carried out to ensure sufficient bacterial cell concentration, while in the second stage (nutrient limitation stage) the bacterial growth rate remains constant but the cells begin to store PHAs intracellularly [62]. The batch fermentation process could also be associated with a low yield of polyhydroxyalkanoates due to the degradation of accumulated PHAs as carbon and energy materials after complete use of the substrate, resulting in a reduced amount of the final product [63].

Batch fermentation has been employed in the investigation and optimization of mcl-PHA homopolymers synthesized by Pseudomonas species [64] investigated the batch production of 3-hydroxyoctanoate [P(3HO)]. The authors reported that $31.38 \%$ of this homopolymer can be produced by Pseudomonas mendocina grown on sodium octanoate. It was reported that Pseudomonas sp. could also utilize aromatic hydrocarbons as a feedstock towards mcl-PHAs with different monomeric compositions. Investigations applying batch fermentations of monoaromatic substrates have shown that the strain was able to synthesize $19.2 \%$ of CDW grown on o-xylene and 3-methylbenzene. The produced mcl-PHAs contained 3-hydroxyoctanoate (3HO), 3-hydroxydecanoate (3HD) and 3-hydroxydodecanoate (3HDD) as the major components and a small amount of 3-hydroxyhexanoate (3HHx). Furthermore, the same monomeric composition was found when Pseudomonas sp. TN301 were grown on naphthalene and achieved higher PHA productivity $(22.9 \mathrm{mg}$ $\mathrm{g} \mathrm{CDW}^{-1}$ ) [47]. Lower mcl-PHA concentration was achieved during two-stage batch cultivation of Pseudomonas aeruginosa ATCC 27853 using oleic, erucic and nervonic acids. In these cases, the PHAs consisted of five monomers, with 3-hydroxyoctanoate and 3-hydroxydecanoate in greater amounts, and 3-hydroxyhexanoate, 3-hydroxydodecanoate, 3-hydroxy-5-tetradecenoate in lesser amounts [43].

Also, extremophiles belong to Pseudomonas genus were employed towards PHA synthesis. Pseudomonas sp. SG4502, a thermophilic bacterium, was reported to produce mcl-PHA up to $40 \%$ of cell dry weight from a biodiesel fuel by-product as a carbon source [65]. Goh and Tan [66] demonstrated that Pseudomonas strains isolated from Antarctic soils were able to synthesize mcl-PHAs. The highest PHAs content ( $48 \%$ of CDW) was achieved in the cultivation of Pseudomonas sp. UMAB-40 growing on octanoate. The accumulated biopolyesters contained mainly 3-hydroxyhexanoate and 3-hydroxyoctanoate and a trace amount of 3-hydroxydecanoate. Pseudomonas extremaustralis 14-3b, a highly stress resistant bacterium isolated from Antarctica, has been extensively studied for its potential in synthesizing PHA. This strain was able to accumulate large quantities of PHB and minor amounts of mcl-PHAs when grown with octanoate or glucose as carbon source [67].

\section{Fed-Batch Cultivation}

A fed-batch culture is a more efficient process than batch cultivation, because it achieves a high bacterial cell density and the highest possible bioproduct concentration [68, 69]. During fed-batch fermentation, the growth medium is supplemented with an additional portion of a substrate. This bioprocess strategy ensures constant regulation of nutrients, avoids carbon limitations and enables the effective growth of microorganisms and bioproduct accumulation [69]. This type of cultivation is the best method for industrial PHA production. It has been demonstrated that co-feeding in fedbatch cultivations could improve PHA production. According to Jiang et al. [70] Pseudomonas putida KT2440 is able to accumulate more mcl-PHAs using acrylic acid together with nonanoic acid and glucose as co-substrates in a fedbatch culture. The authors found that this bacteria synthesized $75.5 \%$ of PHA with $89 \mathrm{~mol} \% \mathrm{HN}$ at a nonanoic acid: glucose: acrylic acid feed mass ratio of 1.25: $1: 0.05$ and a specific growth rate of $0.15 \mathrm{~h}^{-1}$. Lower mcl-PHA content (32\% of CDW) was reported by Davis et al. [54] when nonanoic acid was supplied to the glucose grown cells of the above-mentioned strain without the supply of pure oxygen or oxygen enriched air. Promising results were also published by Chen et al. [53] who demonstrated that a newly-isolated strain TO7 belonging to Pseudomonas mosselli cultivated on palm kernel oil was able to accumulate mcl-PHAs in the concentration of $47.1 \%$ of CDW. However, the feeding of soybean oil lowered the biopolymer content in these bacterial cells up to $28.6 \%$ of CDW [71].

\section{Continuous Cultivations}

Continuous cultivation is recognized as a process that enhances productivity and offers a high consistency and uniformity of product quality, providing long-term genetic stability of the organism [72]. The active biomass concentration, PHA content and substrates are kept constant as soon as steady-state conditions are reached. Cell harvest also occurs continuously under these conditions [73]. However, the use of this cultivation strategy for PHA production using Pseudomonas sp. has been limited with only a few examples. A major disadvantage of this technique seems to be the risk of microbial contamination that can endanger whole fermentation batches and, consequently, cause extensive economic loss [74]. The first continuous mcl-PHA biosynthesis was conducted using Pseudomonas putida GPo1 [75]. The 
authors confirmed that continuous cultivation was a way to provide the bacterial cells with sufficient substrate without an inhibition of substrate concentrations in the culture medium. At the dilution rate of $0.24 \mathrm{~h}^{-1}$ and an increasing carbon/nitrogen ratio, the percentage of PHAs in the biomass was constant (13\% of CDW). When the specific growth rate was below the maximum specific growth rate of $0.3 \mathrm{~h}^{-1}$, the extracted PHAs consist of a constant proportion of monomer composition with a $3 \mathrm{HB} / 3 \mathrm{HHx} / 3 \mathrm{HO} / 3 \mathrm{HD}$ ratio of $0.1: 1.7: 20.7: 1.0$. Due to the effects of higher concentrations of unmetabolised octanoate in the fermentor an increase of $\mu_{\max }$ was observed. It causes a decrease in the percentage of $3 \mathrm{HO}$ with a concomitant increase in $3 \mathrm{HD}$ monomers. Pseudomonas oleovorans ATCC 29347 grown on gaseous octane also forms mcl-PHAs most effectively at growth rates below the maximum specific growth rate in a two-stage continuous system. The connection of two biofermentors in a series was confirmed to be a useful approach to achieve a specific growth rate of bacteria in the first compartment, leading to the generation of PHAs at higher rates in the second compartment. Under the applied conditions, Pseudomonas oleovorans cells synthesized 63\% PHA of CDW in the effluent of the second fermentor. Due to the completely different kinetics of cell growth and mcl-PHA accumulation the above-mentioned two-stage bioprocess seems to be more efficient than a single stage setup. A maximum mcl-PHA accumulation is reached when the cells grow at a $\mu_{\max }$ of $0.21 \mathrm{~h}^{-1}$, whereas $\mu_{\max }$ of Pseudomonas oleovorans is $0.48 \mathrm{~h}^{-1}$ as demonstrated in single-stage chemostat cultures. Recently, Follonier et al. [58] conducted a 3-stage continuous cultivation for the production of mcl-PHAs using Pseudomonas putida KT2440 under elevated pressure. The data indicated that the mcl-PHA content, yield on substrate and volumetric productivity were all found to increase at elevated pressure. It was estimated that the oxygen provided to the culture broth under elevated pressure would be sufficient to triple mcl-PHA productivity in the chemostat system from 3.4 (at 1 bar) to $11 \mathrm{~g} \mathrm{l}^{-1} \mathrm{~h}^{-1}$ (at $3.2 \mathrm{bar}$ ).

\section{Fermentation Process Using Recombinant Pseudomonads}

In addition to the wild strains, efforts have been made to use genetically recombined Pseudomonas strains for enhanced PHA biosynthesis. These bacteria are recognized as being easy to use for molecular manipulations. It is known that to synthesize PHAs containing non-3-hydroxybutyrate monomers the bacterial cultivations should be supplemented with fatty acids as carbon sources [76]. These substrates are metabolized during the $\beta$-oxidation cycle, leading to shortened n-alkanoic acid monomers in the final biopolymer. Therefore, to improve the efficiency of the substrate-to-PHA conversion, $\beta$-oxidation impaired mutants have been constructed. Using lysogeny broth and dodecanoate as cosubstrates $\beta$-oxidation inhibiting mutant of Pseudomonas putida KT2442 was able to form a copolymer containing $4 \mathrm{~mol} \% 3 \mathrm{HHx}, 37 \mathrm{~mol} \% 3 \mathrm{HO}, 20 \mathrm{~mol} \% 3 \mathrm{HD}$ and $39 \mathrm{~mol} \%$ 3HDD [77]. Additional deletion of the gene encoding the 3-hydroxyacyl-CoA dehydrogenase increased 3HDD content to $56 \mathrm{~mol} \%$ [78]. Liu et al. [44] weakened the $\beta$-oxidation pathway by deleting fadB (PP2136), fadA (PP2137), fadB2x (PP2214), fadAx (PP2215) and genes coding 3-hydroxyacylCoA dehydrogenase (PP2047) and acyl-CoA dehydrogenase (PP2048). The recombinant $P$. puitda KT2442 synthesized homopolymer poly-3-hydroxydecanoate [P(3HD)] or copolymer P(3HD-co-84 mol\% 3HDD) growing on decanoate or dodecanoate, respectively. Recently, this recombinant was applied as a random and block co-polymer producer. Tripathi et al. [79] proved that co-monomer compositions could be easily controlled by a predefined ratio of the fatty acids used as carbon sources. According to the authors, Pseudomonas putida KTOYO6 $\Delta \mathrm{C}\left(p h a \mathrm{PCJ}_{\mathrm{A}, \mathrm{c}}\right)$ cultivated on mixtures of sodium butyrate and sodium hexanoate accumulated random copolymers of $\mathrm{P}(3 \mathrm{HB}-\mathrm{co}-3 \mathrm{HHx})$ with a monomer fraction of $3 \mathrm{HHx}$ content ranging from 19 to $75 \mathrm{~mol} \%$. While the $P$. putida KTQQ20 mutant was grown on mixtures of sodium hexanoate and decanoic acid, the recombinant was able to produce random copolymers of $\mathrm{P}(3 \mathrm{HHx}-\mathrm{co}-3 \mathrm{HD})$ with $3 \mathrm{HHx}$ ranging from 16 to $63 \mathrm{~mol} \%$. The authors also demonstrated the capability of the recombinants to synthesize a novel diblock copolymer P3HHx-b-P(3HD-co-3HDD) consisting of $49 \mathrm{~mol} \% \mathrm{P} 3 \mathrm{HHx}$ and $51 \mathrm{~mol} \% \mathrm{P}(3 \mathrm{HD}-\mathrm{co}-3 \mathrm{HDD})$. In addition, a $\beta$-oxidation-deleted Pseudomonas entomophila was used to successfully synthesize biopolyesters. Li et al. [80] proved that stabilization of the PHA monomer structures is possible. The authors used a Pseudomonas entomophila mutant as a platform for the biosynthesis of polyhydroxyalkanoates with adjustable monomer content and composition. They achieved random copolymers of 3-hydroxydodecanoate (3HDD) and 3-hydroxy-9-decenoate (3H9D) confirming that their compositions can be adjusted by ratios of dodecanoic acid (DDA) to 9-decenol (9DEO) fed to the Ps. entomophila culture. Furthermore, it was demonstrated that random copolymers $\mathrm{P}$ (3HDD-co-3H9D) could be crossed-linked under UV-radiation due to the presence of the unsaturated bonds. A stable synthesis of homopolymers of 3-hydroxyvalerate to 4-hydroxytetradecanoate was also applied in the cultivations of Ps. entomophila LAC23 mutant grown on different fatty acids [81].

The genes from other microorganisms have been introduced into Pseudomonas sp. to improve PHA biosynthesis. Le Meur et al. [82] proved that introduction of the genes encoding xylose isomerase (XylA) and xylulokinase (XylB) from E. coli W3110 into Ps. putida KT2440 was sufficient to allow the recombinant to efficiently utilize xylose as the 
sole carbon source. Experiments performed in bioreactors showed that XylA and XylB were active in Ps. putida KT2440. The recombinants produce mcl-PHA up to $20 \%$ of CDW by sequential-feeding strategy using xylose as the growth substrate and octanoic acid as the precursor for mclPHA production. The PHA content of the Ps. putida KT2440 mutant increased by $100 \%$ compared to the parent strain after the single deletion of the $g c d$ gene encoding glucose dehydrogenase. The engineered strain could almost maintain a growth rate at the same level as the wild type [83]. These mutants were also cultured into a high cell density fed-batch with carbon-limiting exponential feeding followed by three different feeding approaches during the PHA accumulation phase (nitrogen-limitation) in the presence of glucose. This approach resulted in 23-fold higher mcl-PHA productivity than with the batch cultivations [84]. The authors successfully deleted $p g l$ gene coding for 6-phosphoglucolactonase. In terms of mcl-PHAs synthesis, the Ps. putida $\Delta g c d-p g l$ mutant strain accumulated $33 \%$ more biopolymers than the wild type KT2440.

\section{PHA Synthesis by Pseudomonas sp. Using Cheap Carbon sources}

Microbial PHA production can not compete with synthetic plastics for large-scale production because of the high cost of bacterial fermentation. The cost of the carbon substrate accounts for about $50 \%$ of the overall production costs. Therefore, there is a growing need for the development of novel microbial processes using inexpensive carbon sources. Such substrates should meet several basic requirements such as an availability in constant amounts and quality throughout the year and should also have the same composition, purity, stability and resistance to deterioration. There are a number of publications which have reviewed the selection of suitable substrates for efficient PHA synthesis and for making this bioprocess economically reasonable $[39,85]$. A detailed overview of microbial PHA synthesis by bacteria belonging to the Pseudomonas species is presented in Table 3.

Many waste plant oils have been tested towards polyhydroxyalkanoates synthesis by Pseudomonas sp. They are not recovered and may cause serious environmental problems. Moreover, the use of plant oil as one of the most efficiently consumed products in the world for biopolymer production could decrease costs and, as a consequence of PHA adoption, may become more widespread. Generally, this bioprocess is associated with lipase activity. However, it was reported that some pseudomonads capable of producing lipase were unable to convert plant oils into biopolymers. Therefore, in some cases, an additional saponification step was conducted [88, 101]. The composition of the monomer fraction of PHAs reflects the composition of plant oils used.
It was confirmed that Pseudomonas sp. cultivated on long fatty acids consisting of from 13-carbon to 18-carbon are able to synthesize PHAs containing 8-carbon and 10-carbon monomers. Możejko et al. [86] demonstrated the ability of Pseudomonas sp. G101 to accumulate 21\% CDW of mclPHAs grown on waste rapeseed oil. The authors reported that 3-hydroxyoctanoate and 3-hydroxydecanoate were the major components of the extracted mcl-PHAs. A much higher mcl-PHA content in the same bacterial strain has been achieved in the fed-batch fermentations using saponified waste palm oil. It has been shown that bacteria are able to synthesize up to $48 \%$ of mcl-PHAs consisting of monomers such as 3-HHx, 3-HDD, 3-HTD. Additionally, up to $63 \mathrm{~mol} \%$ of $3-\mathrm{HN}$ monomer was identified in the extracted biopolymer indicating the presence of uneven fatty acids in the waste palm oil used [88]. According to Sharma et al. [92], the PA23 strain of Pseudomonas chlororaphilis is able to synthesize mcl-PHAs at the lower level of $10.5 \%$ of CDW with a biomass accumulation of $4.6 \mathrm{~g} \mathrm{l}^{-1}$ when grown on waste frying oil. The authors detected 3-hydroxyoctanoate followed by 3-hydroxydecanoate and 3-hydroxydodecanoate as the dominant subunits in the extracted biopolymers.

Recently, it was revealed that other wastes from the food industry like fruit pomace could replace the costly sugars and fatty acids typically used as carbon substrates for the Pseudomonas sp. fermentations. Follonier et al. [90] conducted a two-step fermentation process with Pseudomonas resinovorans, hydrolysed pomace as a growth substrate and waste frying oil as a mcl-PHA precursor. The final biomass concentration was $10.2 \mathrm{~g} \mathrm{l}^{-1}$ and $6.1 \mathrm{~g} \mathrm{l}^{-1}$ for apricots and Solaris grapes pomace, respectively. Interestingly, Solaris grapes proved to be a very promising growth substrate, resulting in the accumulation of $21.3 \mathrm{~g} \mathrm{PHA}^{-1}$ pomace

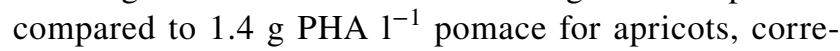
sponding to a volumetric productivity of 0.05 and $0.03 \mathrm{~g}$ mcl-PHA $1^{-1} \mathrm{~h}^{-1}$, respectively. The mcl-PHA composition was very similar in both cases and consisted of a mixture of 3-hydroxyhexanoate, 3-hydroxyoctanoate, 3-hydroxydecanoate, 3-hydroxydodecanoate and 3-hydroxytetradecenoate which is consistent with the fact that these biopolymers were derived from the same precursor substrate.

The increasing demand for biodiesel production worldwide has led to a surplus of crude glycerol as a main byproduct. Disposal of biodiesel-derived glycerol has created problems with waste management and water pollution [102]. Thus, microbial fermentation to convert crude glycerol to value-added products like polyhydroxyalkanoates is an attractive solution. Recently, it was revealed that partiallyrefined glycerol could be utilized towards mcl-PHA synthesis by strain 9.1 belonging to Ps. mediterranea. However, this strain was capable of reaching a cell dry mass of $3 \mathrm{~g}$ $1^{-1}$ with $21 \%$ of mcl-PHA content after $72 \mathrm{~h}$ of the cultivation [94]. Chanasit et al. [95] demonstrated that a maximum 
Table 3 An overview of microbial synthesis of PHAs by Pseudomonas sp. grown on renewable carbon sources

\begin{tabular}{|c|c|c|c|c|c|c|c|c|c|}
\hline Strain & $\begin{array}{l}\text { Cultivation } \\
\text { mode }\end{array}$ & Carbon sources & Biomass $\left(\mathrm{g} \mathrm{l}^{-1}\right)$ & $\begin{array}{l}\text { PHA content } \\
(\%)\end{array}$ & $\mathrm{M}_{\mathrm{w}}(\mathrm{kDa})$ & $\mathrm{M}_{\mathrm{n}}(\mathrm{kDa})$ & $\mathrm{T}_{\mathrm{m}}\left({ }^{\circ} \mathrm{C}\right)$ & $\mathrm{T}_{\mathrm{g}}\left({ }^{\circ} \mathrm{C}\right)$ & References \\
\hline \multicolumn{10}{|c|}{ Food industry wastes } \\
\hline $\begin{array}{l}\text { Pseudomonas } \\
\text { sp. }\end{array}$ & Batch & Waste corn oil & 12.53 & 35.63 & ND & ND & ND & ND & [46] \\
\hline $\begin{array}{l}\text { Pseudomonas } \\
\text { sp. G101 }\end{array}$ & Fed-batch & $\begin{array}{l}\text { Waste rapeseed } \\
\text { oil }\end{array}$ & 5.5 & 21.0 & ND & ND & ND & ND & [86] \\
\hline $\begin{array}{l}\text { Pseudomonas } \\
\text { sp. G106 }\end{array}$ & Fed-batch & $\begin{array}{l}\text { Waste rapeseed } \\
\text { oil }\end{array}$ & 4.8 & 19.3 & ND & ND & ND & ND & {$[86]$} \\
\hline $\begin{array}{l}\text { Pseudomonas } \\
\text { sp. G101 }\end{array}$ & $\begin{array}{l}\text { Two-step fed- } \\
\text { batch }\end{array}$ & $\begin{array}{l}\text { Waste rapeseed } \\
\text { oil }\end{array}$ & 3.0 & 20 & ND & ND & ND & ND & {$[87]$} \\
\hline $\begin{array}{l}\text { Pseudomonas } \\
\text { sp. G101 }\end{array}$ & Fed-batch & Waste palm oil & 3.8 & 43.0 & 109.0 & 65.0 & 86 & -55 & {$[88]$} \\
\hline $\begin{array}{l}\text { Pseudomonas } \\
\text { sp. G101 }\end{array}$ & Fed-batch & $\begin{array}{l}\text { Waste rapeseed } \\
\text { oil }\end{array}$ & 4.4 & 44.0 & 144.0 & 58.0 & 46 & -38 & [89] \\
\hline $\begin{array}{l}\text { Ps. resinovo- } \\
\text { rans }\end{array}$ & $\begin{array}{l}\text { Two-step fed } \\
\text { batch }\end{array}$ & $\begin{array}{l}\mathrm{I}^{\circ} \text {-Apricot } \\
\text { pomace } \\
\mathrm{II}^{\circ} \text { - waste fry- } \\
\text { ing oil }\end{array}$ & 10.2 & 12.4 & ND & ND & ND & ND & {$[90]$} \\
\hline $\begin{array}{l}\text { Ps. resinovo- } \\
\text { rans }\end{array}$ & $\begin{array}{l}\text { Two-step fed } \\
\text { batch }\end{array}$ & $\begin{array}{l}\mathrm{I}^{\circ}-\text { Solaris } \\
\text { grape pomace } \\
\text { II }{ }^{\circ} \text {-waste fry- } \\
\text { ing oil }\end{array}$ & 6.1 & 23.3 & ND & ND & ND & ND & \\
\hline $\begin{array}{r}\text { Ps. putida } \\
\text { KT2440 }\end{array}$ & $\begin{array}{l}\text { Two-step fed } \\
\text { batch }\end{array}$ & $\begin{array}{l}\mathrm{I}^{\circ} \text { _grapes } \\
\text { pomace } \\
\mathrm{II}^{\circ} \text {-octanoic } \\
\text { acid, } 10 \text {-unde- } \\
\text { cenoic acid }\end{array}$ & 14.2 & 41.1 & 139.0 & 70.6 & NO & -45.5 & [91] \\
\hline $\begin{array}{l}\text { Ps. chlo- } \\
\quad \text { roraphilis } \\
\quad \text { PA23 }\end{array}$ & Batch & $\begin{array}{l}\text { Waste canola } \\
\text { fryer oil }\end{array}$ & 4.88 & 10.56 & ND & ND & ND & ND & {$[92]$} \\
\hline \multicolumn{10}{|c|}{ Biodiesel derived-glycerol } \\
\hline $\begin{array}{l}\text { Ps. oleovorans } \\
\quad \text { NRRL } \\
\text { B-14682 }\end{array}$ & Batch & Crude glycerol & 2.9 & 1.1 & 85.0 & 31.0 & ND & ND & [93] \\
\hline $\begin{array}{l}\text { Ps. mediter- } \\
\text { ranea }\end{array}$ & Batch & $\begin{array}{l}\text { Partially refined } \\
\text { glycerol }\end{array}$ & 3.0 & 21 & 55.0 & 41.0 & 40.6 & -40.6 & [94] \\
\hline Ps. mendocina & Batch & $\begin{array}{l}\text { Biodiesel } \\
\text { derived liquid }\end{array}$ & 3.65 & 77 & ND & ND & ND & ND & {$[95]$} \\
\hline $\begin{array}{l}\text { Ps. mediterra- } \\
\quad \text { nea } 9.1\end{array}$ & Batch & Crude glycerol & 4.77 & 61.4 & ND & ND & ND & ND & [96] \\
\hline $\begin{array}{l}\text { Ps. corrugata } \\
\text { A1 }\end{array}$ & Batch & Crude glycerol & 4.72 & 41.9 & ND & ND & ND & ND & \\
\hline $\begin{array}{l}\text { Ps. corrugata } \\
\quad 388\end{array}$ & Batch & Crude glycerol & 4.25 & 28.2 & ND & ND & ND & ND & \\
\hline $\begin{array}{l}\text { Ps. citronello- } \\
\quad \text { lis }\end{array}$ & Fed-batch & $\begin{array}{c}\text { Tallow-based } \\
\text { biodiesel }\end{array}$ & 42 & 26.6 & 78.0 & 19.6 & 53.6 & -43.5 & [97] \\
\hline $\begin{array}{l}\text { Pseudomonas } \\
\text { sp. ASC2 }\end{array}$ & Batch & Crude glycerol & 32.3 & 61.8 & 6.5 & 3.6 & ND & ND & [98] \\
\hline $\begin{array}{c}\text { Ps. chlorora- } \\
\text { phis PA23 }\end{array}$ & Batch & $\begin{array}{l}\text { Biodiesel- } \\
\text { derived free } \\
\text { fatty acids }\end{array}$ & 4.03 & 24.17 & ND & ND & ND & ND & [92] \\
\hline $\begin{array}{l}\text { Ps. mosselii } \\
\text { TO7 }\end{array}$ & Fed-batch & Crude glycerol & 1.31 & 48.4 & 9.7 & 7.5 & 49 & NO & [71] \\
\hline \multicolumn{10}{|c|}{ Sugar refinary wastes } \\
\hline $\begin{array}{l}\text { Ps. fluorescens } \\
\text { A2a5 }\end{array}$ & Batch & $\begin{array}{l}\text { Sugarcane } \\
\text { liquor }\end{array}$ & 32.0 & 70 & ND & ND & ND & ND & [99] \\
\hline
\end{tabular}


Table 3 (continued)

\begin{tabular}{|c|c|c|c|c|c|c|c|c|c|}
\hline Strain & $\begin{array}{l}\text { Cultivation } \\
\text { mode }\end{array}$ & Carbon sources & Biomass $\left(\mathrm{g}^{-1}\right)$ & $\begin{array}{l}\text { PHA content } \\
(\%)\end{array}$ & $\mathrm{M}_{\mathrm{w}}(\mathrm{kDa})$ & $\mathrm{M}_{\mathrm{n}}(\mathrm{kDa})$ & $\mathrm{T}_{\mathrm{m}}\left({ }^{\circ} \mathrm{C}\right)$ & $\mathrm{T}_{\mathrm{g}}\left({ }^{\circ} \mathrm{C}\right)$ & References \\
\hline $\begin{array}{l}\text { Pseudomonas } \\
\text { sp. }\end{array}$ & Batch & Spent wash & 8.56 & 25.46 & ND & ND & ND & ND & [46] \\
\hline $\begin{array}{l}\text { Pseudomonas } \\
\text { sp. }\end{array}$ & Batch & Fermented wash & 7.02 & 23.56 & ND & ND & ND & ND & \\
\hline $\begin{array}{l}\text { Pseudomonas } \\
\text { sp. }\end{array}$ & Batch & Molasses & 10.54 & 20.63 & ND & ND & ND & ND & \\
\hline $\begin{array}{l}\text { Ps. aeruginosa } \\
\text { NCIM } 2948\end{array}$ & Batch & Cane Molasses & 6.63 & 62.44 & ND & ND & ND & ND & [100] \\
\hline
\end{tabular}

$M_{\mathrm{w}}$ weight avaerage molecular weight, $M_{\mathrm{n}}$ number avaerage molecular weight, $T_{g}$ glass transition temperature, $T_{m}$ melting temperature, $N D$ not determined, $N O$ not observed

biomass concentration of $3.65 \mathrm{~g} \mathrm{l}^{-1}$ with a biopolymer content of $77 \% \mathrm{CDW}$ was accumulated by Pseudomonas mendocina PSU when grown with $20 \mathrm{~g} \mathrm{l}^{-1}$ of a biodiesel liquid waste. The authors determined that a higher concentration of the substrate from 30 to $50 \mathrm{~g} \mathrm{l}^{-1}$ caused a reduction in the biomass and PHA content. Other batch cultures of Pseudomonas species have also been employed in the investigation and optimization of mcl-PHA synthesis using biodiesel-derived glycerol. Palmeri et al. [96] extracted 2.93, 1.98 and $1.28 \mathrm{~g} \mathrm{PHA}^{-1}$ from Ps. mediterranea 9.1, Ps. corrugata 388 and $\mathrm{A} 1$ growing on crude glycerol, respectively. The chromatographic profile of PHAs obtained by Ps. corrugata $\mathrm{A} 1$ and 388 strains showed peaks referring to methyl 9-do-decenoate (C12:1), methyl hexadecanoate (C16:0) and methyl 9-hexadecenoate (C16:1). Interestingly, Ps. mediterranea 9.1 chromatogram of PHAs also revealed oleic acid methyl ester (C18:1) and linoleic acid methyl ester (C19:3). Recently, promising results have been published by Liu et al. [71] who cultivated Ps. mosselli TO7 to $1.31 \mathrm{~g} \mathrm{CDW} 1^{-1}$ on waste glycerol. The PHA concentration reached $48 \%$ of CDW with a productivity of $13.16 \mathrm{mg} \mathrm{PHA} \mathrm{l}^{-1} \mathrm{~h}^{-1}$. Tallowbased biodiesel was used by Muhr et al. [97] as a substrate in mcl-PHA production by Ps. citronellolis. In this work, final intracellular PHA contents calculated from the sum of active biomass and PHA reached $26.6 \%$ of CDW. A GC-FID analysis showed that the obtained biopolyester predominantly consists of 3-hydroxyoctanoate and 3-hydroxydecanoate, and lower amounts of 3-hydroxydodecanoate, 3-hydroxynonanoate, 3-hydroxyhexanoate, and 3-hydroxyheptanoate monomers. However, Muangwong et al. [98] reported that Pseudomonas sp. ACS2 utilized crude glycerol to synthesize up to $61.8 \%$ of CDW of a copolymer poly ( $5 \mathrm{~mol} \% 3$-hydroxyoctanoate-co-95 mol\% 3-hydroxy-5-cis-dedecanoate).

Molasses, a common industrial by-product of sugar production, is widely available and is much cheaper than glucose. Since it consists of about $50 \%$ sucrose along with a significant amount of fructose and glucose, it seems to be a good carbon source for PHA production in the biological processes. However, only a few studies have been conducted into the utilization of molasses for biopolymer synthesis. Jiang et al. [99] observed the production of $70 \%$ of polyhydroxyalkanoates with the highest cell concentration of $32 \mathrm{~g}$ $1^{-1}$ when the cultivation was supplemented with sugarcane liquor. In addition, other by-products from the sugar industry have been found to be good substrates for the growth of Pseudomonas sp. and for subsequent PHA production. A maximum PHA content was observed in the first $24 \mathrm{~h}$ of the cultivations, resulting in $25.46 \%, 23.56 \%$ and $20.65 \%$ of biopolymers when Pseudomonas sp. grown on spent wash, fermented mash and molasses, respectively [46]. Furthermore, Tripathi et al. [103] successfully utilized cane molasses for the PHA production using Pseudomonas aeruginosa NCIM 2948. A cell density of $6.6 \mathrm{~g} \mathrm{l}^{-1}$ and a total PHA content of $62.4 \% \mathrm{CDW}$ were determined after $60 \mathrm{~h}$ of the fermentation process.

\section{Material Properties and Applications of Polyhydroxyalkanoates Synthesized by Pseudomonas sp.}

Polyhydroxyalkanoates have similar properties to synthetic polymers like polypropylene or polystyrene. PHAs vary considerably in their chemical, mechanical and physical properties. The properties of mcl-PHAs are different from sclPHAs. The characteristics of the final biopolymer depend on PHA producer, the fermentation mode and conditions used during the bioprocess. Scl-PHAs are highly crystalline, brittle and stiff. Their melting temperature $\left(\mathrm{T}_{\mathrm{m}}\right)$ ranges from 173 to $180{ }^{\circ} \mathrm{C}$ and the glass transition temperature $\left(\mathrm{T}_{\mathrm{g}}\right)$ lies between 5 and $9{ }^{\circ} \mathrm{C}$. However, mcl-PHAs are thermoelastomers with low $\mathrm{Tm}$ ranging between 40 and $86^{\circ} \mathrm{C}$ and $\mathrm{Tg}$ values between -50 and $-25^{\circ} \mathrm{C}$ [104].

Generally, glass and melting transition temperature are important parameters that determine in-service application of polyhydroxyalkanoates. They evaluate the temperature 
limits for potential applications, especially for semicrystalline polymers. The thermal properties of mcl-PHAs accumulated by Pseudomonas citronelloli showed a Tm value in the range of $53.6^{\circ} \mathrm{C}$ with a $\Delta \mathrm{Hm}$ of about $20 \mathrm{~J} / \mathrm{g}$. These values indicate that the samples are not totally amorphous but partially crystalline with classical rubber-to-latex-like characteristics [83]. This might be due to an assembling of both the main and the side chains of the polymer in a layered order as frequently observed for other polymers harbouring long side chains [105]. Higher thermal values were determined for scl-copolymer by Allen et al. [42] who cultivated Pseudomonas oleovorans ATCC29347 on Jatropha curcas oil. DSC thermograms showed a poly(3-hydroxybutyrateco-3-hydroxyvalerate) copolymer melting temperature of up to $160{ }^{\circ} \mathrm{C}$. However, so far the highest reported $\mathrm{T}_{\mathrm{m}}$ value to date of the mcl-PHAs isolated from Pseudomonas sp. grown on waste substrates was $86^{\circ} \mathrm{C}$ [88].

The molecular weight of polyhydroxyalkanoates is regarded as a parameter affecting their properties. Number $\left(\mathrm{M}_{\mathrm{n}}\right)$ and weight $\left(\mathrm{M}_{\mathrm{w}}\right)$ average molecular weights of mclPHAs are lower compared to those of scl-PHAs. Phukon et al. [52] reported that $M_{w}$ and $M_{n}$ for poly(3-hydroxyvalerate-co-5-hydroxydecenoate) copolymer synthesizing by Pseudomonas aeruginosa BP C1 grown on glucose were 5.986 and $5.648 \mathrm{Da}$, respectively. The polydispersity index $\left(I=M_{w} / M_{n}\right)$ bears a narrow value of 1.059 , which suggests possession of uniform chain length what is essential for the food and pharmaceutical industries as it does not require further processing for polymer chain uniformity. In contrast, Impallomeni et al. [55] demonstrated that supplementation of long odd-chain fatty acids led to the higher molecular weight values $\left(\mathrm{M}_{\mathrm{w}}\right)$ of mcl-PHAs from Pseudomonas aeruginosa ATCC 27853 which ranged from 77 to $188 \mathrm{~kg} \mathrm{~mol}^{-1}$.

PHAs have useful properties such as: biodegradability, biocompatibility, non-toxicity, thermoplasticity. In view of their properties they are promising biopolymers in the medical field. Their applications have focused on drug delivery carrier matrix [106], bone tissue engineering [107, 108] and cartilage tissue engineering [109]. In recent years, polyhydroxyalkanoates and their copolymers, and composites have been considered as polymers suitable to develop bone marrow scaffolds, cardiovascular patches, orthopaedic pins, stents, guided tissue repair or regeneration devices, articular cartilage repair devices, nerve guides, tendon repair devices, sutures and wound dressings [110].

Recently, it has been reported that polyhydroxyalkanoates synthesized by Pseudomonas sp. could be promising biopolymers in pharmacy. Chung et al. [111] cultivated genetically modified Pseudomonas entomophila to produce 3-hydroxyalkanoates as precursors for the synthesis of value-added chemicals including antibiotics, pharmaceuticals, vitamins. Furthermore, the biodegradable mcl-PHAs produced by Pseudomonas putida CA-3 was tested to enhance the anti-cancer activity of peptides. O'Connor et al. [112] purified from the mixture of 3-HHx, 3-HO, 3-HD and 3-HDD the dominant monomer 3-hydroxydecanoic acid (R10). This monomer was conjugated to DP18 peptide containing D-amino acids and its derivatives. It was revealed that the conjugated peptides (R10DP18L) improved anti-proliferation activity that appears to be mediated through grater uptake into the cells.

Furthermore, high immunotolerance and low toxicity are the benefits associated with PHAs in tissue engineering. In the study conducted by Naveen et al. [10] the suitability of an unmodified/raw mcl-PHAs (uMCL-PHA) extracted from Pseudomonas putida grown on saponified palm kernel oil as a novel scaffold for a future tissue-engineered products was investigated. The authors revealed that uMCLPHA supports mesenchymal stromal cell attachment. It was confirmed that the cell viability was not affected in mclPHA film, a significant increase in cells proliferation was evaluated in day 6 compared to the initial time point (day 3). Also, P(3HB-co-3HHx) was tested as a scaffold using human embryonic stem cells (hESCs), spontaneously differentiated hESCs (SDhESCs) and mesenchymal stem cells (hMSCs). The results showed that undifferentiated hESCs are not viable after 20 days of culture within a PHBHHx/ collagen gel hybrid scaffold, whereas hMSCs and SDhESCs demonstrated good viability over the long-term with an overall lack of stimulus-independent differentiation [113]. Lukasiewicz et al. [114] describe an approach to tuning the poor mechanical properties of $\mathrm{P}(3 \mathrm{HB})$ using mcl-PHAs, as a plasticizer precursor, synthesized by Pseudomonas mendocina $\mathrm{CH} 50$ during a two-step fed batch cultivation supplemented with waste frying oil as a carbon source. The authors confirmed that an addition of oligomeric bacterial mcl-PHA to $\mathrm{P}(3 \mathrm{HB})$ resulted in softer and more flexible material with a dominant amorphous phase, giving it potential for application in unique soft tissue engineering. Furthermore, this novel binary PHA polymer was proven to be biocompatible without any cytotoxic effects. It showed high viability and proliferation of $\mathrm{C} 2 \mathrm{C} 12$ myoblast cells relevant to skeletal muscle and cardiac tissue engineering.

In addition, polyhydroxyalkanoates synthesized by Pseudomonas sp. have been studied as potential biomaterials for stent development. Basnett et al. [115] studied the composite of $\mathrm{P}(3 \mathrm{HO}) /$ bacterial cellulose which was prepared by solvent casting. The $\mathrm{P}(3 \mathrm{HO})$ was produced by Pseudomonas mendocina grown on sodium octanoate as the sole carbon source. The mechanical properties of the prepared matrix film were significantly improved e.g. the tensile strength was found to be higher compared to the neat $\mathrm{P}(3 \mathrm{HO})$ film. Thermal characterization of the neat as well as the composite films using DSC showed that there was an increase in the glass transition temperature while the melting temperature of the composite films decreased in comparison to the homopolymer 
films. Furthermore, an in vitro degradation study confirmed that the inclusion of the acetylated cellulose microcrystals in the $\mathrm{P}(3 \mathrm{HO})$ films increased the degradation rate of the composite films in comparison to the neat $\mathrm{P}(3 \mathrm{HO})$ film in both PBS and DMEM media. In addition, on the composite film, increased cell growth and proliferation of MEC-1 cells compared to the neat $\mathrm{P}(3 \mathrm{HO})$ film was observed. The same $\mathrm{P}(3 \mathrm{HO})$ homopolymer was used to develop a novel blend with $\mathrm{P}(3 \mathrm{HB})$. In addition, in this case, the blended films exhibited better mechanical and thermal properties. They were found to be highly biocompatible with significantly higher overall protein absorption and cell viability compared to the neat $\mathrm{P}(3 \mathrm{HO})$ film [116].

\section{Concluding Remarks}

Due to current problems with the harmful effects of synthetic plastic materials and increasing concerns about oil shortages, governments and industries put much effort into the development of natural and biodegradable polymers. Polyhydroxyalkanoates are one of the most promising biopolymers that could replace petroleum-based plastics in the future. During more than 90 years of PHA-related research, great progress has been made regarding its biosynthesis, metabolic and genetic regulation and applications. Because of its biodegradability, biocompatibility and nontoxicity, PHAs can be used in many industrial fields ranging from everyday products to medical applications. However, the high manufacturing costs hamper their synthesis on a large scale.

Many bacteria are able to synthesize PHAs, but the Pseudomonas species seems to be a potential cell factory for the production of these biopolyesters. Pseudomonas sp. without any doubt could become a platform bacterium that is capable of accumulating defined PHAs structures and constant biopolymer properties. Many studies have been carried out so far into improving their biomass concentration, PHA formation and properties. Advances in molecular biology have also helped to improve PHA yields through genetic engineering of bioproducers belonging to the Pseudomonas species. However, a greater understanding of genetic and metabolic regulation could lead to the construction of a suitable bacterial platform that will be able to provide a consistent PHA molecular structure to ensure constant material properties which determine their applications. Metabolically-engineered Pseudomonas sp. seems to be capable of synthesizing PHAs at the high concentration. The abovementioned data confirm that genetic manipulation of PHA biosynthetic pathways could considerably enhance the final productivity of the biofermentations. Furthermore, a better understanding of the regulation of genes involved in PHAs synthesis and accumulation will be helpful to improve their content in bacterial cells and help to isolate new biopolymer films useful in many applications.

One of the major limitations of the industrial production of PHAs is the final cost mainly depending on the price of carbon sources added for microbial growth. Research into the biological synthesis of PHAs should aim at improving the cost-effectiveness and the efficiency of their recovery. The limited knowledge of the PHAs central biochemical network when using low-cost carbon sources hampers the use of Pseudomonas in such endeavours. To make the PHAs synthesis process by Pseudomonas sp. more feasible, it is essential to put greater effort into the high-throughput screening of potentially new bacterial producers and to optimize the fermentation process using renewable carbon sources. Discontinuous fed-batch cultivations are mainly used for large scale production of PHA. Low volumetric rate or unpredictable bioproduct quality are some of the drawbacks that should be taken into account employing such processes [117]. Therefore, to improve the PHAs productivity, the optimization processes using continuous mode of operation needs to be implemented. Furthermore, the development of a multistage bioreactor cascade could result in production of novel block-co-polyesters with unique properties.

Acknowledgements This work was supported by the National Science Center (Poland), Project No. 2014/15/D/NZ9/04255. The authors have no conflict of interest to declare.

\section{Compliance with Ethical Standards}

Conflict of interest The authors declare that they have no conflict of interest.

Open Access This article is distributed under the terms of the Creative Commons Attribution 4.0 International License (http://creativeco mmons.org/licenses/by/4.0/), which permits unrestricted use, distribution, and reproduction in any medium, provided you give appropriate credit to the original author(s) and the source, provide a link to the Creative Commons license, and indicate if changes were made.

\section{References}

1. Singh P, Sharma VP (2016) Integrated plastic waste management: environmental and improved health approaches. Procedia Environ Sciences 35:692-700. https://doi.org/10.1016/j.proen v.2016.07.068

2. Shen L, Haufe J, Patel M (2009) Product overview and market projection of emerging bio-based plastic. PRO-BIP, Utrecht

3. Laycock B, Arcos-Hernandez M, Langford A, Pratt S, Werker A, Halley P, Lant P (2014) Crystallisation and fractionation of selected polyhydroxyalkanoates produced from mixed cultures. New Biotechnol 31(4):345. https://doi.org/10.1016/j. nbt.2013.05.005

4. Lemoigne M (1926) Produits de deshydratation et de polymersation de la acideoxybutyrique. Bull Soc Chim Biol 8:770-782 
5. Dietrich K, Dumont MJ, Del Rio LF, Orsat V (2017) Producing PHAs in the bioeconomy: towards a sustainable bioplastic. Sustain Prod Consum 9:58-70. https://doi.org/10.1016/j. spc.2016.09.001

6. European Bioplastics, Nova-Institute (2018) Bioplastics market data 2018. Global production capacities of bioplastics 20182023. https://www.european-bioplastics.org/wp-content/uploa ds/2016/02/Report_Bioplastics-Market-Data_2018.pdf

7. Muhammadi S, Afzal M, Hameed S (2015) Bacterial polyhydroxyalkanoates-eco-friendly next generation plastic: production, biocompatibility, biodegradation, physical properties and applications. Green Chem Lett Rev 8:56-77. https://doi. org/10.1080/17518253.2015.1109715

8. Poblete-Castro I, Rodriguez AL, Lam CMC, Kessler W (2014) Improved production of medium-chain-length polyhydroxyalkanoates in glucose-based fed-batch cultivations of metabolically engineered Pseudomonas putida strains. J Microbiol Biotechnol 24(1):59-69. https://doi.org/10.4014/jmb.1308.08052

9. Naveen SV, Tan IKP, Goh YS, Raghavendran HRB, Murali MR, Kamarul T (2015) Unmodified medium chain length polyhydroxyalkanoate (uMCL-PHA) as a thin film for tissue engineering application: characterization and in vitro biocompatibility. Mater Lett 141:55-58. https://doi.org/10.1016/j.matle t.2014.10.144

10. Pereira JR, Araújo D, Marques AC, Neves LA, Grandfils C, Sevrin C, Alves VD, Fortunato E, Reis MAM, Freitas F (2019) Demonstration of the adhesive properties of the medium-chainlength polyhydroxyalkanoate produced by Pseudomonas chlororaphis subsp. aurantiaca from glycerol. Int J Biol Macromol 122:1144-1151. https://doi.org/10.1016/j.ijbiomac.2018.09.064

11. Obruca S, Sedlacek P, Koller M, Kucera D, Pernicova I (2018) Involvement of polyhydroxyalkanoates in stress resistance of microbial cells: biotechnological consequences and applications. Biotechnol Adv 36:856-870. https://doi.org/10.1016/j.biotechadv 2017.12.006

12. Sedlacek P, Slaninova E, Koller M, Nebesarova J, Marova I, Krzyzanek V, Obruca S (2019) PHA granules help bacterial cells to preserve cell integrity when exposed to sudden osmotic imbalances. New Biotechnol 49:129-136. https://doi.org/10.1016/j. nbt.2018.10.00

13. Obruca S, Sedlacek P, Krzyzanek V, Mravec F, Hrubanova K, Samek O, Kucera D, Benesova P, Marova I (2016) Accumulation of poly(3-hydroxybutyrate) helps bacterial cells to survive freezing. PLoS ONE 11:e0157778. https://doi.org/10.1371/journ al.pone. 0157778

14. Obruca S, Sedlacek P, Mravec F, Samek O, Marova I (2016) Evaluation of 3-hydroxybutyrate as an enzyme-protective agent against heating and oxidative damage and its potential role in stress response of poly(3-hydroxybutyrate) accumulating cells. Appl Microbiol Biotechnol 100:1365-1376. https://doi. org/10.1007/s00253-015-7162-4

15. Bresan S, Sznajder A, Hauf W, Forchhammer K, Pfeier D, Jendrossek D (2016) Polyhydroxyalkanoate (PHA) granules have no phospholipids. Sci Rep 6:26612. https://doi.org/10.1038/srep2 6612

16. Tian J, He A, Lawrence AG, Liu P, Watson N, Sinskey AJ, Stubbe J (2005) Analysis of transient polyhydroxybutyrate production in Wautersia eutropha $\mathrm{H} 16$ by quantitative western analysis and transmission electron microscopy. J Bacteriol 187:3825-3832. https://doi.org/10.1128/JB.187.11.3825-3832.2005

17. Khanna S, Srivastava AK (2005) Recent advances in microbial polyhydroxyalkanoates. Process Biochem 40(2):607-619. https ://doi.org/10.1016/j.procbio.2004.01.053

18. Tan D, Wu Q, Chen JC, Chen GQ (2014) Engineering halomonas TD01 for the low-cost production of polyhydroxyalkanoates.
Metab Eng 26:34-47. https://doi.org/10.1016/j.ymben 2014.09.001

19. Mravec F, Obruca S, Krzyzanek V, Sedlacek P, Hrubanova K, Samek O, Kucera D, Benesova P, Nebesarova J (2016) Accumulation of PHA granules in Cupriavidus necator as seen by confocal fluorescence microscopy. FEMS. Microbiol Lett 363(10):fnw094. https://doi.org/10.1093/femsle/fnw094

20. Rehm BH (2007) Biogenesis of microbial polyhydroxyalkanoate granules: a platform technology for the production of tailor-made bioparticles. Curr Issues Mol Biol 9:41-62. https ://doi.org/10.21775/cimb.009.041

21. Philip S, Keshavarz T, Roy I (2007) Polyhydroxyalkanoates: biodegradable polymers with a range of applications. J Chem Technol Biotechnol 82(3):233-247. https://doi.org/10.1002/ jctb. 1667

22. Kunasundari B, Sudesh K (2011) Isolation and recovery of microbial polyhydroxyalkanoates. Express Polym Lett 5(7):620 634. https://doi.org/10.3144/expresspolymlett.2011.60

23. Steinbüchel A, Valentin HE (1995) Diversity of bacterial polyhydroxyalkanoic acids. FEMS Microbiol Lett 128(3):219-228. https://doi.org/10.1111/j.1574-6968.1995.tb07528.x

24. Madison LL, Huisman GW (1999) Metabolic engineering of poly(3-hydroxyalcanoates): from DNA to plastic. Microbiol Mol Biol Rev 63(1):21-53

25. Hoffmann N, Steinbüchel A, Rehm BHA (2000) The Pseudomonas aeruginosa phaG gene product is involved in the synthesis of polyhydroxyalkanoic acid consisting of medium-chain-length constituents from non-related carbon sources. FEMS Microbiol Lett 184:253-259. https://doi. org/10.1111/j.1574-6968.2000.tb09023.x

26. Park M, Gonzalez-Sulser A, Vaucheret H, Poethig R (2005) Nuclear processing and export of microRNAs in Arabidopsis. Proc Natl Acad Sci USA 102(10):3691-3696. https://doi. org/10.1073/pnas.0405570102

27. Qi Q, Rehm B (2001) Polyhydroxybutyrate biosynthesis in Caulobacter crescentus: molecular characterization of the polyhydroxybutyrate synthase. Microbiology 147:3353-3358. https:// doi.org/10.1099/00221287-147-12-3353

28. Slater S, Gallaher T, Dennis D (1992) Production of poly-(3-hydroxybutyrate-co-3-hydroxyvalerate) in a recombinant Escherichia coli strain. Appl Environ Microbiol 58(4):1089-1094. doi: 0099-2240/92/041089-06\$02.00/0

29. Sandoval A, Arias-Barrau E, Arcos M, Naharro G, Olivera ER, Luengo JM (2007) Genetic and ultrastructural analysis if different mutants of Pseudomonas putida affected in the poly-3-hydroxy-n-alkanoate gene cluster. Environ Microbiol 9(3):737-751. https://doi.org/10.1111/j.1462-2920.2006.01196.x

30. Klinke S, de Roo G, Witholt B, Kessler B (2000) Role of phaD in accumulation of medium-chain-length poly(3hydroxyalkanoates) in Pseudomonas oleovorans. Appl Environ Microbiol 66(9):3705-3710. https://doi.org/10.1128/ AEM.66.9.3705-3710.2000

31. Galán B, Dinjaski N, Maestro B, de Eugenio LI, Escapa IF, Sanz JM, García JL, Prieto MA (2011) Nucleoid-associated PhaF phasin drives intracellular location and segregation of polyhydroxyalkanoate granules in Pseudomonas putida KT2442. Mol Microbiol 79:402-418. https://doi.org/10.111 1/j.1365-2958.2010.07450.x

32. Obeso JI, Gómez-Botrán JL, Olivera ER, Luengo JM (2015) The phasin PhaF controls bacterial shape and size in a networkforming strain of Pseudomonas putida. J Biotechnol 199:17-20. https://doi.org/10.1016/j.jbiotec.2015.01.022

33. Sierro NJM (2005) Bi-functionality of the PhaF protein of Pseudomonas putida in the polyhydroxyalkanoate production process. Doctoral thesis, Swiss Federal Institute of Technology, Zurich. https://doi.org/10.3929/ethz-a-004924840 
34. Prieto A, Escapa IF, Martínez V, Dinjaski N, Herencias C, de la Peña F, Tarazona N, Revelles O (2016) A holistic view of polyhydroxyalkanoate metabolism in Pseudomonas putida. Environ Microbiol 18(2):341-357. https://doi. org/10.1111/1462-2920.12760

35. Hoffmann N, Rehm BH (2004) Regulation of polyhydroxyalkanoate biosynthesis in Pseudomonas putida and Pseudomonas aeruginosa. FEMS Microbiol Lett 237:1-7. https://doi. org/10.1016/j.femsle.2004.06.029

36. Możejko-Ciesielska J, Pokój T, Ciesielski S (2018) Transcriptome remodeling of Pseudomonas putida KT2440 during mclPHAs synthesis: effect of different carbon sources and response to nitrogen stress. J Ind Microbiol Biotechnol 45:433-446. https ://doi.org/10.1007/s10295-018-2042-4

37. Możejko-Ciesielska J, Dąbrowska D, Szalewska-Pałasz A, Ciesielski S (2017) Medium-chain-length polyhydroxyalkanoates synthesis by Pseudomonas putida KT2440 relA/spoT mutant: bioprocess characterization and transcriptome analysis. AMB Express 7:92. https://doi.org/10.1186/s13568-017-0396-z

38. Lee WH, Azizan MNM, Sudesh K (2004) Effect of culture conditions of poly(3-hydroxybutyrate-co-4-hydroxybutyrate) synthesized by Comamonas acidovorans. Polym Degrad Stab 84(1):129-134. https://doi.org/10.1016/j.polymdegradstab .2003 .10 .003

39. Chanprateep S (2010) Current trends in biodegradable polyhydroxyalkanoates. J Biosci Bioeng 110:621-632. https://doi. org/10.1016/j.jbiosc.2010.07.014

40. Możejko-Ciesielska J, Kiewisz R (2016) Bacterial polyhydroxyalkanoates: still fabulous? Microbiol Res 192:271-282. https:// doi.org/10.1016/j.micres.2016.07.010

41. Kenny ST, Runic JN, Kaminsky W, Woods T, Babu RP, Keely CM, Blau W, O'Connor KE (2008) Up-cycling of PET (polyethylene terephthalate) to the biodegradable plastic PHA (polyhydroxyalkanoates). Environ Sci Technol 42(20):7696-7701. https ://doi.org/10.1021/es801010e

42. Allen AD, Anderson WA, Ayorinde FO, Eribo BE (2010) Biosynthesis and characterization of copolymer poly (3HB-co-3HV) from saponified jatropha curcas oil by Pseudomonas oleovorans. J Ind Microbiol Biotechnol 37:849-856. https://doi.org/10.1007/ s10295-010-0732-7

43. Impallomeni G, Ballistreri A, Carnemolla GM, Guglielmino SP, Nicolo MS, Cambria MG (2011) Synthesis and characterization of poly(3-hydroxyalkanoates) from Brassica carinata oil with high content of erucic acid and from very long chain fatty acids. Int J Biol Macromol 48:137-145. https://doi.org/10.1016/j.ijbio mac.2010.10.013

44. Liu Q, Luo G, Zhou XR, Chen GQ (2011) Biosynthesis of poly (3-hydroxydecanoate) and 3-hydroxydodecanoate dominating polyhydroxyalkanoates by $\beta$-oxidation pathway inhibited Pseudomonas putida. Metab Eng 13(1):11-17. https://doi. org/10.1016/j.ymben.2010.10.004

45. Wang HH, Zhou XR, Liu Q, Chen GQ (2011) Biosynthesis of polyhydroxyalkanoate homopolymers by Pseudomonas putida. Appl Microbiol Biotechnol 89(5):1497-1507. https://doi. org/10.1007/s00253-010-2964-x

46. Chaudhry WN, Jamil N, Ali I, Ayaz MH, Hasnain S (2011) Screening for polyhydroxyalkanoate (PHA)-producing bacterial strains and comparison of PHA production from various inexpensive carbon sources. Ann Microbiol 61:623-629. https://doi. org/10.1007/s13213-010-0181-6

47. Narancic T, Kenny ST, Djokic L, Vasiljevic B, O'Connor KE, Nikodinovic-Runic J (2012) Medium-chain-length polyhydroxyalkanoate production by newly isolated Pseudomonas sp. TN301 from a wide range of polyaromatic and monoaromatic hydrocarbons. J Appl Microbiol 113(3):508-520. https://doi.org/10.111 1/j.1365-2672.2012.05353.x
48. Cerrone F, Choudhari SK, Davis R, Cysneiros D, O'Flaherty V, Duane G, Casey E, Guzik MW, Kenny ST, Babu RP, O'Connor K (2014) Medium chain length polyhydroxyalkanoate (mcl-PHA) production from volatile fatty acids derived from the anaerobic digestion of grass. Appl Microbiol Biotechnol 98:611-620. https ://doi.org/10.1007/s00253-013-5323-x

49. Gumel AM, Annuar MSM, Heidelberg T (2014) Growth kinetics, effect of carbon substrate in biosynthesis of mcl-PHA by Pseudomonas putida Bet001. Braz J Microbiol 45:427-438

50. Wang Q, Nomura TC (2010) Monitoring differences in gene expression levels and polyhydroxyalkanoate (PHA) production in Pseudomonas putida KT2440 grown on different carbon sources. J Biosci Bioeng 6:653-659. https://doi.org/10.1016/j. jbiosc.2010.08.001

51. Satoh Y, Tajima K, Nakamoto S, Xuerong H, Matsushima T, Ohshima T, Kawano S, Erata T, Dairi T, Munekata M (2011) Isolation of a thermotolerant bacterium producing medium-chain-length polyhydroxyalkanoate. J Appl Microbiol 111(4):811-817. https://doi.org/10.111 1/j.1365-2672.2011.05093.x

52. Phukon P, Pokhrel B, Konwar BK, Dolui SK (2013) Biosynthesis and characterization of a new copolymer, poly(3-hydroxyvalerate-co-5-hydroxy-decenoate), from Pseudomonas aeruginosa. Biotechnol Lett 35:607-611. https://doi.org/10.1007/s1052 9-012-1119-9

53. Chen Y, Huang Y, Lee C (2014) Production and characterization of medium-chain-length polyhydroxyalkanoates by Pseudomonas mosselii TO7. J Biosci Bioeng 118:145-152. https:// doi.org/10.1016/j.jbiosc.2014.01.012

54. Davis R, Duane G, Kenny ST, Cerrone F, Guzik MW, Babu RP, Casey E, O'Connor KE (2014) High cell density cultivation of Pseudomonas putida KT2440 using glucose without the need for oxygen enriched air supply. Biotechnol Bioeng 112:725-733. https://doi.org/10.1002/bit.25474

55. Impallomeni G, Ballistreri A, Carnemolla GM, Rizzo MG, Nicolò MS, Guglielmino SPP (2018) Biosynthesis and structural characterization of polyhydroxyalkanoates produced by Pseudomonas aeruginosa ATCC 27853 from long odd-chain fatty acids. Int J Biol Macromol 108:608-614. https://doi. org/10.1016/j.ijbiomac.2017.12.037

56. Jung K, Hazenberg W, Prieto M, Witholt B (2001) Twostage continuous process development for the production of medium-chain-length poly(3-hydroxyalkanoates). Biotechnol Bioeng 72:19-24. https://doi.org/10.1002/1097-0290(20010 105)72:1\%3C19::AID-BIT3\%3E3.0.CO;2-B

57. Hartmann R, Hany R, Geiger T, Egli T, Witholt B, Zinn M (2004) Tailored Biosynthesis of olefinic medium-chain-length poly[(R)-3-hydroxyalkanoates] in Pseudomonas putida GPo1 with improved thermal properties. Macromolecules 37:67806785. https://doi.org/10.1021/ma040035

58. Follonier S, Henes B, Panke S, Zinn M (2012) Putting cells under pressure: a simple and efficient way to enhance the productivity of medium-chain-length polyhydroxyalkanoate in processes with Pseudomonas putida KT2440. Biotechnol Bioeng 109:451-461. https://doi.org/10.1002/bit.23312

59. Kaur G, Roy I (2015) Strategies for large-scale production of polyhydroxyalkanoates. Chem Biochem Eng Q 29(2):157-172. https://doi.org/10.15255/CABEQ.2014.2255

60. Kim GJ, Lee IY, Yoon SC, Shin YC, Park YH (1997) Enhanced yield and a high production of medium-chain-length poly(3hydroxyalkanoates) in a twostep fed-batch cultivation of Pseudomonas putida by combined use of glucose and octanoate. Enzyme Microb Tech 20(7):500-505. https://doi.org/10.1016/ S0141-0229(96)00179-2

61. Chee JY, Yoga SS, Lau NS, Ling SC, Abed RM, Sudesh K (2010) PHA bacterially produced polyhydroxyalkanoate. Converting 
renewable resources into 42 bioplastics. In: Mendez-Vilas A (ed) Current research, technology and education topics in applied microbiology and microbial biotechnology. Formatex Research Center, Badajoz, pp 1395-1404

62. Lee SY (1996) Plastic bacteria? Progress and prospects for polyhydroxyalkanoate production in bacteria. Trends Biotechnol 14(11):431-438. https://doi.org/10.1016/0167-7799(96)10061-5

63. Zinn M, Witholt B, Egli T (2001) Occurrence, synthesis and medical application of bacterial polyhydroxyalkanoate. Adv Drug Del Rev 53(1):5-21. https://doi.org/10.1016/S0169 -409X(01)00218-6

64. Rai R, Yunos DM, Boccaccini AR, Knowles JC, Barker IA, Howdle SM, Tredwell GD, Keshavarz T, Roy I (2011) Poly3-hydroxyoctanoate $\mathrm{P}(3 \mathrm{HO})$, a medium chain length polyhydroxyalkanoate homopolymer from Pseudomonas mendocina. Biomacromol 12(6):2126-2136. https://doi.org/10.1021/ bm2001999

65. Satoh Y, Tajima K, Nakamoto S, Xuerong H, Matsushima T, Ohshima T, Kawano S, Erata T, Dairi T, Munekata M (2011) Isolation of a thermotolerant bacterium producing mediumchain-length polyhydroxyalkanoate. J App Microbiol 111:811817. https://doi.org/10.1111/j.1365-2672.2011.05093.x

66. Goh YS, Tan IKP (2012) Polyhydroxyalkanoate production by antarctic soil bacteria isolated from Casey Station and Signy Island. Microbiol Res 167:211-219. https://doi.org/10.1016/j. micres.2011.08.002

67. Catone MV, Ruiz JA, Castellanos M, Segura D, Espin G, López NI (2014) High polyhydroxybutyrate production in pseudomonas extremaustralis is associated with differential expression of horizontally acquired and core genome polyhydroxyalkanoate synthase genes. PLoS ONE 9:e98873-e98873. https://doi.org/10.1371/journal.pone.0098873

68. Chee JY, Tan Y, Samian MR, Sudesh K (2010) Isolation and characterization of a Burkholderia sp. USM (JCM15050) capable of producing polyhydroxyalkanoate (PHA) from triglycerides, fatty acids and glycerols. J Polym Environ 18:584-592. https://doi.org/10.1007/s10924-010-0204-1

69. Kaur G, Srivastava A, Chand S (2012) Advances in biotechnological production of 1, 3-propanediol. Biochem Eng J 64:106-118. https://doi.org/10.1016/j.bej.2012.03.002

70. Jiang XJ, Sun Z, Ramsay JA, Ramsay BA (2013) Fedbatch production of MCL-PHA with elevated 3-hydroxynonanoate content. AMB Express 3:50. https://doi. org/10.1186/2191-0855-3-50

71. Liu MH, Chen YJ, Lee CY (2018) Characterization of mediumchain-length polyhydroxyalkanoate biosynthesis by Pseudomonas mosselii TO7 using crude glycerol. Biosci Biotechnol Biochem 82(3):532-539. https://doi.org/10.1080/09168 451.2017.1422386

72. Lillo JG, Rodriguez-Valera F (1990) Effects of culture conditions on poly(beta-hydroxybutyric acid) production by Haloferax mediterranei. Appl Environ Microbiol 56(8):2517-2521

73. Koller M, Muhr A (2014) Continuous production mode as a viable process-engineering tool for efficient poly(hydroxyalkanoate) (PHA) bio-production. Chem Biochem Eng Q 28(1):65-77

74. Koller M, Braunegg G (2015) Potential and prospects of continuous polyhydroxyalkanoate (PHA) production. Bioengineering 2(2):94-121. https://doi.org/10.3390/bioengineering2020094

75. Ramsay BA, Saracovan I, Ramsay JA, Marchessault RH (1991) Continuous production of long-side-chain poly-beta-hydroxyalkanoates by Pseudomonas oleovorans. Appl Environ Microbiol 57(3):625-629

76. Chen GQ, Jiang XR (2017) Engineering bacteria for enhanced polyhydroxyalkanoates (PHA) biosynthesis. Synth Syst Biotechnol 2:192-197. https://doi.org/10.1016/j.synbio.2017.09.001
77. Ouyang SP, Liu Q, Fang L, Chen GQ (2007) Construction of pha-operon-defined knockout mutants of Pseudomonas putida KT2442 and their applications in poly(hydroxyalkanoate) production. Macromol Biosci 7(2):227-233. https://doi.org/10.1002/ mabi.200600187

78. Ma L, Zhang HF, Liu Q, Chen J, Zhang J, Chen GQ (2009) Production of two monomer structures containing medium-chainlength polyhydroxyalkanoates by $\beta$-oxidation-impaired mutant of Pseudomonas putida KT2442. Bioresour Technol 100(20):48914894. https://doi.org/10.1016/j.biortech.2009.05.017

79. Tripathi L, Wu LP, Dechuan M, Chen J, Wu Q, Chen GQ (2013) Pseudomonas putida KT2442 as a platform for the biosynthesis of polyhydroxyalkanoates with adjustable monomer contents and compositions. Bioresour Technol 142:225-231. https://doi. org/10.1016/j.biortech.2013.05.027

80. Li S, Cai L, Wu L, Zeng G, Chen J, Wu Q, Chen GQ (2014) Microbial synthesis of functional homo-, random, and block polyhydroxyalkanoates by $\beta$-oxidation deleted Pseudomonas entomophila. Biomacromol 15(6):2310-2319. https://doi. org/10.1021/bm500669s

81. Wang Y, Chung A, Chen GQ (2017) Synthesis of mediumchain-length polyhydroxyalkanoate homopolymers, random copolymers, and block copolymers by an engineered strain of Pseudomonas entomophila. Adv Healthc Mater 6(7):1-10. https ://doi.org/10.1002/adhm.201601017

82. Le Meur S, Zinn M, Egli T, Thöny-Meyer L, Ren Q (2012) Production of medium-chain-length polyhydroxyalkanoates by sequential feeding of xylose and octanoic acid in engineered Pseudomonas putida KT2440. BMC Biotechnol 12:53. https:// doi.org/10.1186/1472-6750-12-53

83. Poblete-Castro I, Binger D, Rodrigues A, Becker J, Martins dos Santos VAP, Wittmann C (2013) In-silico-driven metabolic engineering of Pseudomonas putida for enhanced production of polyhydroxyalkanoates. Metab Eng 15:113-123. https://doi. org/10.1016/j.ymben.2012.10.004

84. Poblete-Castro I, Binger D, Oehlert R, Rohde M (2014) Comparison of mcl-poly(3-hydroxyalkanoates) synthesis by different Pseudomonas putida strains from crude glycerol: citrate accumulates at high titer under PHA-producing conditions. BMC Biotechnol 14:962. https://doi.org/10.1186/s12896-014-0110-z

85. Ciesielski S, Możejko-Ciesielska J, Pisutpaisal N (2015) Plant oils as promising substrates for polyhydroxyalkanoates production. J Clean Prod 106:408-421. https://doi.org/10.1016/j.jclep ro.2014.09.040

86. Możejko J, Przybyłek G, Ciesielski S (2011) Waste rapeseed oil as a substrate for medium-chain-length polyhydroxyalkanoates production. Eur J Lipid Sci Tech 113(12):1550-1557. https://doi. org/10.1002/ejlt.201100148

87. Możejko J, Wilke A, Przybyłek G, Ciesielski S (2012) Mcl-PHAs produced by Pseudomonas sp. G101 using fed-batch cultivation with waste rapeseed oil as carbon source. J Microbiol Biotechnol 22(3):371-377. https://doi.org/10.4014/jmb.1106.06039

88. Możejko J, Ciesielski S (2013) Saponified waste palm oil as an attractive renewable resource for mcl-polyhydroxyalkanoate synthesis. J Biosci Bioeng 116(4):485-492. https://doi. org/10.1016/j.jbiosc.2013.04.014

89. Możejko J, Ciesielski S (2014) Pulsed feeding strategy is more favorable to medium-chain-length polyhydroxyalkanoates production from waste rapeseed oil. Biotechnol Prog 30(5):12431246. https://doi.org/10.1002/btpr.1914

90. Follonier S, Goyder MS, Silvestri AC, Crelier S, Kalman F, Riesen R, Zinn M (2014) Fruit pomace and waste frying oil as sustainable resources for the bioproduction of medium-chainlength polyhydroxyalkanoates. Int J Biol Macromol 71:42-52. https://doi.org/10.1016/j.ijbiomac.2014.05.061 
91. Follonier S, Riesen R, Zinn M (2015) Pilot- scale production of functionalized mcl-PHA from grape pomace supplemented with fatty acids. Chem Biochem Eng Q 29:113-121. https://doi. org/10.1002/bit.23312

92. Sharma PK, Munir RI, de Kievit T, Levin DB (2017) Synthesis of polyhydroxyalkanoates (PHAs) from vegetable oils and free fatty acids by wild-type and mutant strains of Pseudomonas chlororaphis. Can J Microbiol 63(12):1009-1024. https://doi. org/10.1139/cjm-2017-0412

93. Ashby RD, Solaiman DKY, Strahan GD (2011) Efficient utilization of crude glycerol as fermentation substrate in the synthesis of poly(3-hydroxybutyrate) biopolymers. J Am Oil Chem Soc 88:949-959. https://doi.org/10.1007/s11746-011-1755-6

94. Pappalardo F, Fragalà M, Mineo PG, Damigella A, Catara AF, Palmeri R, Rescifina A (2014) Production of filmable mediumchain-length polyhydroxyalkanoates produced from glycerol by Pseudomonas mediterranea. Int J Biol Macromol 65:89-96. https ://doi.org/10.1016/j.ijbiomac.2014.01.014

95. Chanasit W, Hodgson B, Sudesh K, Umsakul K (2016) Efficient production of polyhydroxyalkanoates (PHAs) from Pseudomonas mendocina PSU using a biodiesel liquid waste (BLW) as the sole carbon source. Biosci Biotechnol Biochem 80:1440-1450. https ://doi.org/10.1080/09168451.2016.1158628

96. Palmeri R, Pappalardo F, Fragalà M, Tomasello M, Damigella A, Catara AF (2012) Polyhydroxyalkanoates (PHAs) production through conversion of glycerol by selected strains of Pseudomonas mediterranea and Pseudomonas corrugata. Chem Eng Trans 27:121-126. https://doi.org/10.3303/CET1227021

97. Muhr A, Rechberger EM, Salerno A, Reiterer A, Schiller M, Kwiecień M, Adamus G, Kowalczuk M, Strohmeier K, Schober S, Mittelbach M, Koller M (2013) Biodegradable latexes from animal-derived waste: biosynthesis and characterization of mcl-PHA accumulated by Ps. citronellolis. React Funct Polym 73(10):1391-1398. https://doi.org/10.1016/j.reactfunctpolym .2012 .12 .009

98. Muangwong A, Boontip T, Pachimsawat J, Napathorn SC (2016) Medium chain length polyhydroxyalkanoates consisting primarily of unsaturated 3-hydroxy-5-cis-dodecanoate synthesized by newly isolated bacteria using crude glycerol. Microb Cell Fact 17:15-55. https://doi.org/10.1186/s12934-016-0454-2

99. Jiang Y, Song X, Gong L, Li P, Dai C, Shao W (2008) High poly( $\beta$-hydroxybutyrate) production by Pseudomonas fluorescens A2a5 from inexpensive substrates. Enzyme Microb Technol 42:167-172. https://doi.org/10.1016/j.enzmictec.2007.09.003

100. Tripathi AD, Yadav A, Jha A, Srivastava SK (2012) Utilizing of sugar refinery waste (cane molasses) for production of bioplastic under submerged fermentation process. J Polym Environ 20(2):446-453. https://doi.org/10.1007/s10924-011-0394-1

101. Silva-Queiroz SR, Silva LF, Pradella JG, Pereira EM, Gomez JG (2009) $\mathrm{PHA}_{\mathrm{MCL}}$ biosynthesis systems in Pseudomonas aeruginosa and Pseudomonas putida strains show differences on monomer specificities. J Biotechnol 143(2):111-118. https://doi. org/10.1016/j.jbiotec.2009.06.014

102. Sharma AK, Sahoo PK, Singhal S, Patel A (2016) Impact of various media and organic carbon sources on biofuel production potential from Chlorella spp. 3 Biotech 6:116. https://doi. org/10.1007/s13205-016-0434-6

103. Tripathi L, Wu LP, Chen J, Chen GQ (2012) Synthesis of diblock copolymer poly-3-hydroxybutyrate -block-poly-3-hydroxyhexanoate [PHB-b-PHHx] by a $\beta$-oxidation weakened Pseudomonas putida. Microb Cell Fact KT2442(1):44. https:// doi.org/10.1186/1475-2859-11-44 11).

104. Rai R, Keshavarz T, Roether JA, Boccaccini AR, Roy I (2011) Medium chain length polyhydroxyalkanoates, promising new biomedical materials for the future. Mater Sci Eng R Rep 72(3):29-47. https://doi.org/10.1016/j.mser.2010.11.002
105. Chen GQ (2010) Industrial production of PHA. In: Chen GQ, Steinbüchel A (eds) Plastics from bacteria, Natural functions and applications. Springer, Münster, pp 121-132

106. Panith N, Assavanig A, Lertsiri S, Bergkvist M, Surarit R, Niamsiri N (2016) Development of tunable biodegradable polyhydroxyalkanoates microspheres for controlled delivery of tetracycline for treating periodontal disease. J Appl Polym Sci 133(42):44128-44140. https://doi.org/10.1002/app.44128

107. Karahaliloglu Z, Ercan B, Taylor EN, Chung S, Denkbas EB, Webster TJ (2015) Antibacterial nanostructured polyhydroxybutyrate membranes for guided bone regeneration. J Biomed Nanotechnol 11(12):2253-2263. https://doi.org/10.1166/ jbn.2015.2106

108. Akaraonye E, Filip J, Safarikova M, Salih V, Keshavarz T, Knowles JC, Roy I (2016) P(3HB) based magnetic nanocomposites: smart materials for bone tissue engineering. J Nanomater 9:1-14. https://doi.org/10.1155/2016/3897592

109. Ching KY, Andriotis OG, Li S, Basnett P, Su B, Roy I, Tare RS, Sengers BG, Stolz M (2016) Nanofibrous poly(3-hydroxybutyrate)/poly(3-hydroxy-octanoate) scaffolds provide a functional microenvironment for cartilage repair. J Biomater Appl 31:77-91. https://doi.org/10.1177/0885328216639749

110. Zhang J, Shishatskaya EI, Volova TG, da Silva LF, Chen GQ (2018) Polyhydroxyalkanoates (PHA) for therapeutic applications. Mater Sci Eng C 86:144-150. https://doi.org/10.1016/j. msec.2017.12.035

111. Chung AL, Zeng GD, Jin HL, Wu Q, Chen JC, Chen GQ (2013) Production of medium-chain-length 3-hydroxyalkanoic acids by $\beta$-oxidation and phaC operon deleted Pseudomonas entomophila harboring thioesterase gene. Metab Eng 17:23-29. https://doi. org/10.1016/j.ymben.2013.02.001

112. O'Connor S, Szwej E, Nikodinovic-Runic J, O’Connor A, Byrne AT, Devocelle M, O'Donovan N, Gallagher WM, Babu R, Kenny ST, Zinn M, Zulian QR, O'Connor KE (2013) The anti-cancer activity of a cationic anti-microbial peptide derived from monomers of polyhydroxyalkanoate. Biomaterials 34(11):2710-2718. https://doi.org/10.1016/j.biomaterials.2012.12.032

113. Lomas AJ, Webb WR, Han J, Chen GQ, Sun X, Zhang Z, El Haj AJ, Forsyth NR (2013) Poly (3-hydroxybutyrate-co-3-hydroxyhexanoate)/collagen hybrid scaffolds for tissue engineering applications. Tissue Eng Part C 19(8):577-585. https://doi. org/10.1089/ten.TEC.2012.0457

114. Lukasiewicz B, Basnett P, Nigmatullin R, Matharu R, Knowles JC, Roy I (2018) Binary polyhydroxyalkanoate systems for soft tissue engineering. Acta Biomater 71:225-234. https://doi. org/10.1016/j.actbio.2018.02.027

115. Basnett P, Knowles JC, Pishbin F, Smith C, Keshavarz T, Boccaccini AR, Roy I (2012) Novel biodegradable and biocompatible poly(3-hydroxy-octanoate)/bacterial cellulose composites. Adv Eng Mater 14:B330-B343. https://doi.org/10.1002/adem.20118 0076

116. Basnett P, Ching KY, Stolz M, Knowles JC, Boccaccini AR, Smith C, Locke IC, Keshavarz T, Roy I (2013) Novel poly(3hydroxyoctanoate)/poly(3-hydroxybutyrate) blends for medical applications. React Funct Polym 73:1340-1348. https://doi. org/10.1016/j.reactfunctpolym.2013.03.019

117. Kosseva MR, Rusbandi E (2018) Trends in the biomanufacture of polyhydroxyalkanoates with focus on downstream processing. Int J Biol Macromol 107:762-778. https://doi.org/10.1016/j.ijbio mac.2017.09.054

Publisher's Note Springer Nature remains neutral with regard to jurisdictional claims in published maps and institutional affiliations. 